Article

\title{
Context Matters: Economic Voting in the 2009 and 2014 European Parliament Elections
}

\author{
Martin Okolikj ${ }^{1, *}$ and Stephen Quinlan ${ }^{2}$ \\ ${ }^{1}$ School of Politics and International Relations, University College Dublin, Dublin 4, Ireland; \\ E-Mail: martin.okolikj@ucdconnect.ie \\ ${ }^{2}$ GESIS Leibniz Institute, 68159 Mannheim, Germany; E-Mail: stephen.quinlan@gesis.org \\ * Corresponding author
}

Submitted: 30 September 2015 | Accepted: 24 November 2015 | Published: 29 February 2016

\begin{abstract}
Using the 2009 and 2014 European Election Studies (EES), we explore the effect of the economy on the vote in the 2009 and 2014 European Parliament (EP) elections. The paper demonstrates that the economy did influence voters in both contests. However, its impact was heterogeneous across the two elections and between countries. While assessments of the economy directly motivated voters in 2009 by 2014 economic appraisals were conditioned by how much responsibility voters felt the national government had for the state of the economy, implying a shift in calculus between the two elections. The analysis suggests that voters in 2009 were simply reacting to the economic tsunami that was the Global Financial Crisis, with motivations primarily driven by the unfavourable economic conditions countries faced. But in 2014, evaluations were conditioned by judgments about responsibility for the economy, suggesting a more conscious holding to account of the government. Our paper also reveals cross-country differences in the influence of the economy on vote. Attribution of responsibility and economic evaluations had a more potent impact on support for the government in bailout countries compared to non-bailout countries in 2014. Our findings demonstrate the importance of economy on vote in EP elections but also highlight how its impact on vote can vary based on context.
\end{abstract}

\section{Keywords}

bailout; economic voting; European elections; global financial crisis; perceptions of economic responsibility

Issue

This article is part of the issue "How Different Were the European Elections of 2014?", edited by Wouter van der Brug, Katjana Gattermann and Claes de Vreese (University of Amsterdam, The Netherlands).

(C) 2016 by the authors; licensee Cogitatio (Lisbon, Portugal). This article is licensed under a Creative Commons Attribution 4.0 International License (CC BY).

\section{Introduction}

Between 2008 and 2014 the advanced industrial world faced its greatest economic challenge since the Great Depression of the late 1920s. The Global Financial Crisis (GFC) saw unemployment across the European Union (EU) rise to unprecedented levels, prolonged periods of negative economic growth, a series of banks come close to collapse forcing national and EU institutions to step in and preserve them, national deficits spiral, and the true indebtedness of many EU member states become evident. Such were the scale of eco- nomic problems that serious questions were raised regarding the ability of the Euro currency to survive (e.g. Eichengreen, 2013; Hotten, 2011). Eight member states (Cyprus, Greece, Hungary, Ireland, Latvia, Portugal, Romania and Spain) were forced to seek so-called 'bailouts' between 2008 and 2013, where the International Monetary Fund (IMF) and the EU provided finances to these countries to enable them to keep their ships of state afloat. Support came with the proviso that these countries would implement a series of austere economic measures, including salary cuts and reduced public services. Austerity became the economic 
orthodoxy of most member states with the GFC also having a number of political repercussions including the ejection from office of many governments in power at the time the GFC hit (LeDuc \& Pammett, 2013), the development of new anti-establishment political movements across Europe, and a dampening of enthusiasm towards the EU (Treib, 2014). Taken together, all of this ensured the economy has been the dominant preoccupation of both citizens and governments alike over the past eight years and in this context, it is reasonable to assume economics has been a key issue, if not the key issue, on voters' minds as they went to the ballot box during this period.

Previous studies have shown the potency of the economy on the vote (e.g. Dassonneville \& Lewis-Beck, 2014; Duch \& Stevenson, 2008; Lewis-Beck \& Paldam, 2000; Lewis-Beck \& Stegmaier, 2013). During economic crises, the economy becomes even more salient (Dassonneville \& Lewis-Beck, 2014; Singer, 2011), as the media gives greater coverage to the issue (Soroka, 2006). This is evidenced by the fact economics were front and centre in the recent national elections of countries adversely affected by the GFC (e.g. CostaLobo, 2013; Fraile \& Lewis-Beck, 2013; Marsh \& Mikhaylov, 2014; Nezi, 2012; Nezi \& Katsanidou, 2014).

Economics have also been shown to shape attitudes towards European integration (e.g. Gabel, 1998; Tucker, Pacek, \& Berinsky, 2002) and preferences in EU referendums (e.g. Doyle \& Fidrmuc, 2006; Elkink, Quinlan, \& Sinnott, 2015). However, its influence on vote choice in European Parliament elections has been explored much less. Traditionally, EP elections have been considered 'second-order', with voter behaviour conditioned by attitudes to the incumbent government (e.g. Hix \& Marsh, 2011; Marsh, 1998; Reif \& Schmitt, 1980; Schmitt \& Teperoglou, 2015). More recently, there has been an appreciation that other reasons also influence voters in EP contests (e.g. de Vries, van der Brug, van Egmond, \& van der Eijk, 2011; Hobolt \& Spoon, 2012). Our claim is that economics are another crucial component, especially in light of the Global Financial Crisis. Therefore, our paper focuses on how the economy motivated vote choice in the 2009 and 2014 European elections.

There has never been a more apt time to explore the motivations underlying citizen behaviour in EP elections given the increasing powers of the European Parliament (Hix, 2013; Hobolt, 2014). EP elections are among the few means citizens have to pass judgment on the EU and thus, exploring what motivates voters in these contests is valuable. Studying behaviour in European elections is all the more interesting considering the 2014 elections marked an attempt by the EU to make European elections "different" from previous EP contests by introducing spitzenkandidaten, where parties at the European level proposed rival candidates for the Presidency of the European Commission. It was hoped by offering voters the opportunity of voting for an executive office and providing a link between voter preferences and selection of the Commission might create more interest in the elections and add a greater 'European' dimension to contests that have been classically characterised as 'second-order' (Hobolt, 2014). However, if vote choice is motivated by attitudes to the national economy as we suspect, this would undermine the idea that European elections were anything but elections where voters were motivated by domestic matters. Accordingly, assessing the influence of the national economy on vote is relevant. Additionally, few studies of EP elections have focused on the link between economics and vote (for an exception see Tilley, Garry, \& Bold, 2008) and those that have done have done so through the prism of the 'second-order' model and in periods of general economic calm. But the 2009 and 2014 contests where held in the midst and aftermath of the Crisis. Couple this with the prominent role European institutions have played in shaping member states responses to the GFC, there is merit in reassessing its impact in these circumstances.

We develop a set of expectations about how the economy influenced vote choice in the 2009 and 2014 EP elections. In line with previous scholarship which has highlighted the importance of context (e.g. Anderson, 2000; Powell Jnr. \& Whitten, 1993; Whitten \& Palmer, 1999), we argue the impact of economy on vote is heterogeneous across both elections and countries. We expect that in 2009 economic perceptions directly influenced vote as the poll took place as the GFC was taking root and the effects were only becoming obvious. It also offered the first opportunity for most European citizens to have their say at the ballot box in a national contest, and thus a direct link is anticipated. By 2014, we expect the economy still influences vote but voter calculus might have shifted. We suggest voters' economic assessments will be conditioned by how much responsibility for economic performance they attribute to the national government. Building on a large literature that shows voter ascriptions of responsibility matter (e.g. de Vries, Edwards, \& Tilman, 2011; Hellwig \& Coffey, 2011; Marsh \& Tilley, 2009; Tilley \& Hobolt, 2011), we expect this change of calculus to be driven by a mixture of factors including that governments in power at the time of the GFC hit had been dismissed in many countries (LeDuc \& Pammett, 2013), the initial shock of the GFC had dissipated with voters now well accustomed to the economic realities post-crisis, and voters by this point were now adjudicating on their government's response to the economic crisis, as much as responding to the economic context themselves. Thus, we expect the more a government is perceived to be responsible for economic performance, the stronger economic voting will be.

Our third expectation relates exclusively to the 2014 elections. We posit the impact of the economy on the vote might vary between countries based on whether a state received external financial aid or not in 
the preceding six years. The reasoning is simplebailout and non-bailout countries had different economic experiences with the crisis more pronounced in the former compared with the latter, with 'bailout states' having been more constrained as they were subject to scrutiny from external institutions. Consequently, we suggest the impact of economics on vote in 2014 will be more potent in countries that received a bailout.

Using a series of multivariate models based on data from the 2009 and 2014 European Election Study (EES), our expectations are largely borne out. Our analysis advances our understanding of economic voting and European elections in numerous ways. First, we demonstrate that during the economic crisis and its aftermath, economic perceptions played an important role in determining vote in the European Elections, challenging previous research suggesting economic voting in EP contests were minimal (Tilley et al., 2008). Second, we show economic perceptions influence on vote in EP elections are conditional on context, with perceptions being a direct motivator of vote choice in 2009 but economic assessments impact on vote conditioned by ascriptions of responsibility in 2014. This highlights the extent to which economic voting, while robust and clearly evident, is conditioned by context. Third, the idea that the 2014 EP elections were any different from past European elections is severely undermined. Clearly, EP elections retain a distinct and strong national flavour.

We structure our article as follows: we begin by reviewing the economic voting literature, defining our conception of economic voting, and then developing three hypotheses to test its impact on vote in the 2009 and 2014 EP elections. In section 3, we describe our research strategy and data. Section 4 details our empirical results while section 5 provides a summary of our results and their implications.

\section{Theory}

\subsection{Defining the Mechanisms of Economic Voting in EP Elections}

"It's the economy, stupid!" - the phrase coined by Bill Clinton's campaign team during his run for the American Presidency in 1992 stresses the importance political campaigns credit to the economy's impact on voters. And they do not appear to be wrong for the economy has been shown to influence vote time and again crossnationally (e.g. Duch \& Stevenson, 2008; Lewis-Beck \& Stegmaier, 2013; Lewis-Beck \& Paldam, 2000; LewisBeck, Nadeau, \& Elias, 2008; Singer, 2011). Economic voting comes in three forms: valence, positional, and patrimonial (Lewis-Beck, Nadeau, \& Foucault, 2013). Traditionally, the valence model has gained most attention and is based on the premise that when voters consider the economy to be doing well, they are more likely to vote for the government, and conversely, when it is perceived to be underperforming, they are more likely to vote against them. This reward-punishment axiom has led Anderson (2007, p. 277) to note that "given citizens limited willingness and capacity to process complex information about politics, rewards and punishment should most easily be detectable with regard to the performance of the economy-after all, the economy is perhaps the most perennially talked-about issue". The economy is especially likely to be salient during an economic crisis (Dassonneville \& Lewis-Beck, 2014; Singer, 2011). If we couple this with the fact that ideologically motivated voting has been declining, fewer citizens now have a predisposition to vote for a particular party (e.g. Dalton, 2006), and valence issues are more prominent than ever (e.g. Clarke, Sanders, Stewart, \& Whiteley, 2009), we expect the economy will impact vote.

While an abundance of literature suggests a strong link between economy and vote, critics argue partisan bias heavily distorts voters' economic perceptions. In the words of Bartels (2002, p.138) "partisan loyalties have pervasive effects on perceptions of the political world". Thus, some scholars (e.g. Evans \& Anderson, 2006; Wlezien, Franklin, \& Twiggs, 1997) have contended political predispositions contaminate attitudes towards the economy and that economic assessments have no independent effect of their own. Assertions of endogeneity have been met with vigorous counterclaims that even when it can be fully teased out (for example using panel data and an instrumental variable approach), there is persuasive evidence to showing economics have a direct effect on vote, and if anything, cross-sectional analysis may suppress the true impact of economic voting (e.g. Fraile \& Lewis-Beck, 2014; Lewis-Beck, Nadeau, \& Elias, 2008). Our room for manoeuver in this analysis is limited as we only have access to cross-sectional data. However, we are buoyed by scholarship that shows even when endogeneity concerns can be conclusively addressed, the strong impact of economy on vote persists. As means of allaying concerns to the extent we can, we do control for partisanship in our models and do draw inferences across two cross-sectional samples rather than one. While not circumventing the endogeneity issue completely, this does allow us to have greater confidence in our conclusions than we otherwise might.

Much debate also rages about the mechanisms underlying economic voting. Existing research recognizes two different facets. First is whether voters are motivated by sociotropic or egocentric rationales, and second whether voters base their opinions on retrospective or prospective judgments. We deal with each in turn below.

Sociotropic motivations assume voters act according to their perception of the overall macroeconomic situation in their country while egocentric motivations are predicated on 'personal' utility with voters deciding on the basis of their personal economic gain or loss 
(Nannestad \& Paldam, 1994). While we do not discount the possibility some voters in EP elections might be egocentric, we suspect most are motivated by sociotropic utility. We come to this view not only because most research suggests sociotropic considerations drive economic voting more (e.g. Anderson, 2000; Lewis-Beck \& Stegmaier, 2013), but also because of the nature of EP contests. As elections are taking place simultaneously across the EU, we suspect benchmarking (Kayser \& Peress, 2012) is more likely to take hold, where citizens compare the economic performance of their countries to others, and in doing so, are more likely to be making sociotropic rather than pocketbook comparisons. In any event, our measure of economic performance only allows us to explore sociotropic motivations.

Another area of debate is whether voters base their judgments on retrospective or prospective evaluations. Retrospective assessments assume voters' decisions are based on the past performance of the government and follow the premise that politicians are held accountable for their actions (Woon, 2012). On the other hand, such an assumption is incompatible with the idea that voters are forward-looking (e.g. Ashworth \& Bueno de Mesquita, 2008; Gordon \& Huber, 2007). Consequently, many argue that when casting a vote, the electorate are thinking about how politicians will handle the economy in the future (Woon, 2012). Besides the stronger evidence of retrospective voting (e.g. Duch \& Stevenson, 2008; Lewis-Beck \& Stegmaier, 2013), we assume that the characteristics of EP elections, particularly those of 2009 and 2014, makes retrospective voting much more likely. Voters in EP elections are not voting for a government and consequently are unlikely to judge the prospect of future economic dividends accruing from the election of individuals to the European Parliament, especially as the EU's economic power is distributed across a range of institutions from the Commission to the European Central Bank. ${ }^{1}$ In sum, we expect economic voting in EP elections to be sociotropic and retrospective.

\subsection{Economic Voting in the European Parliament Elections of 2009 and 2014}

Our interest lies in deciphering the impact of the economy on vote in the 2009 and 2014 European elections. Traditionally European elections have been studied from the 'second-order' perspective with vote choice considered to be primarily influenced by attitudes to the incumbent government (e.g. Hix \& Marsh, 2011;

\footnotetext{
1 While the 2014 EP elections were predicated on the idea of citizens being able to vote for an executive office, we maintain this was not equivalent to voting for a government because while the EP election results are taken into account in the selection of the Commission President, selection of Commissioners remains the purview of national governments.
}

Reif \& Schmitt, 1980; Schmitt, 2005). In recent years, other reasons beyond 'second-order' stimuli such as attitudes towards integration and citizens level of sophistication have been shown to influence voters as well (e.g. de Vries, van der Brug, van Egmond, \& van der Eijk, 2011; Hobolt \& Spoon, 2012). Nonetheless, EP elections continue to have a 'second-order' dimension, with elections campaigns dominated by domestic issues, low voter turnout, and established parties and incumbent governments losing votes (e.g. Cordero \& Montero, 2015; Quinlan \& Okolikj, 2016; Schmitt \& Teperoglou, 2015). Accordingly, we would expect to find support for valence economic voting in EP elections with voters judging government performance on a domestic issue (the national economy).

Yet few studies have explored economic voting in EP elections. A notable exception is Tilley et al.'s (2008) analysis of economic voting in the 2004 contest. They concluded economic voting was limited and only observable among sophisticated voters and in countries that had single party governments in power. A more comprehensive assessment of economic voting using European election data comes from van der Brug, van der Eijk, and Franklin (2007). Using data from the European Election Studies between 1989 and 1999, they found that while the economy matters it is just one factor among many that influences vote. Further, its impact depends on its saliency as an issue, leading them to conclude that while the economy matters, its impact is not quite as important as we might have assumed. However, a re-assessment of the economy's impact on vote in EP elections is in order considering the GFC, which has put the economy front and centre of political debate since 2008 and seen EU institutions take a prominent role in dealing with the fallout from the Crisis. Given these circumstances, it can be expected the economy might have influenced vote choice to a greater extent in 2009 and 2014.

But how might the economy have shaped vote in 2009 and 2014? An abundance of research has previously demonstrated that context conditions economic voting (e.g. Anderson, 2000; Powell Jnr. \& Whitten, 1993). We suppose context will also mediate the impact of economy in EP elections too and that its influence will vary across both elections and countries. Let us first take the differences between 2009 and 2014 polls. We suspect economic perceptions will have directly influenced vote in 2009 considering that the Crisis was still evolving, with the ramifications of the GFC only becoming gradually clear. The fallout consumed voters as unemployment rose, GDP declined, member states debt levels increased, and significant majorities of citizens across the Union judged their national economic circumstances as poor (see Figure 1). The 2009 EP elections also represented the first opportunity for most voters to pass judgment on the Crisis in nationwide elections. Of the twenty-seven member states, 
only in Lithuania had voters been to the polls since the GFC's critical tipping point of September 2008. ${ }^{2}$ Given these circumstances, we expect economic perceptions directly influenced vote in 2009.

We infer that the economy still matters in 2014 but as the contextual circumstances were different at this point, we posit voter calculus will have shifted. By this stage, six years had elapsed since the GFC took hold and while many countries were still dealing with the fallout from it, the global economy had stabilized to an extent. In many member states, the economic outlook was looking better both at a macro level and in terms of citizen perceptions (for e.g. see Figure 2). Furthermore, many governments in power when the Crisis took hold had been dismissed. Thus, while we still expect economic perceptions to matter, we expect voters will take a wider view and incorporate how responsible they felt the government to be for the economic circumstances in 2014. A large literature has highlighted that ascriptions of responsibility matter (e.g. de Vries, Edwards, \& Tilman, 2011; Hellwig \& Coffey, 2011; Hobolt \& Tilley, 2014; Marsh \& Tilley, 2009; Powell Jnr. \& Whitten, 1993). We contend responsibility attribution matters in 2014 because voters will have had time to absorb the shock of the GFC, and having already dismissed many governments in power at the time of the GFC, evaluations of new governments' handling of the

${ }^{2}$ While the active phase of the GFC can be dated to early 2007, September 2008 remains an important crunch point in its evolution with the collapse of Lehman Brothers Bank in the United States and inter-bank lending seizing up, triggering a global economic shock which resulted in a number of European banks failing, stock indexes plummeting, and governments being forced to intervene in the economy in unprecedented ways. economy should become more prominent. Hence, we expect perceptions of economic responsibility (PER) will matter in 2014, and that they will condition economic voting. The more responsibility voters credit to the government for the economy, the more likely they are to vote for/against them, depending on whether they assess the economy to be performing good or bad.

Two critiques might be levelled at our suppositions. The first relates to the methodological issue of restricted variance regarding individual economic perceptions. Given the devestating effects of the GFC, there is an expectation that as everybody thought the economy was performing badly, at least in 2009, there might be little variation to explore (for more see Fraile \& LewisBeck, 2014). However, inspection of citizens' views about economic performance at the time shows a more nuanced picture. Figures 1 and 2 detail the distribution of economic perceptions by country. In 2009 (Figure 1) sufficient numbers of citizens in most member states had an alternative view to the conventional wisdom that the economy was performing poorly, although in some countries this respresented a small proportion of the electorate. Our cross-national strategy aids us here as with evaluations varying between countries, there is suficient variance overall to explore economic perceptions legitimately. Thus, we do not believe the restricted variance problem is something that plagues our analysis to a sufficient extent. Additionally, these distributions support our idea that as voter perceptions of the economy have changed between 2009 and 2014 (which inspection of Figures 1 and 2 by country illustrate they clearly have), this might play into economic voting being different between the two elections and between countries.

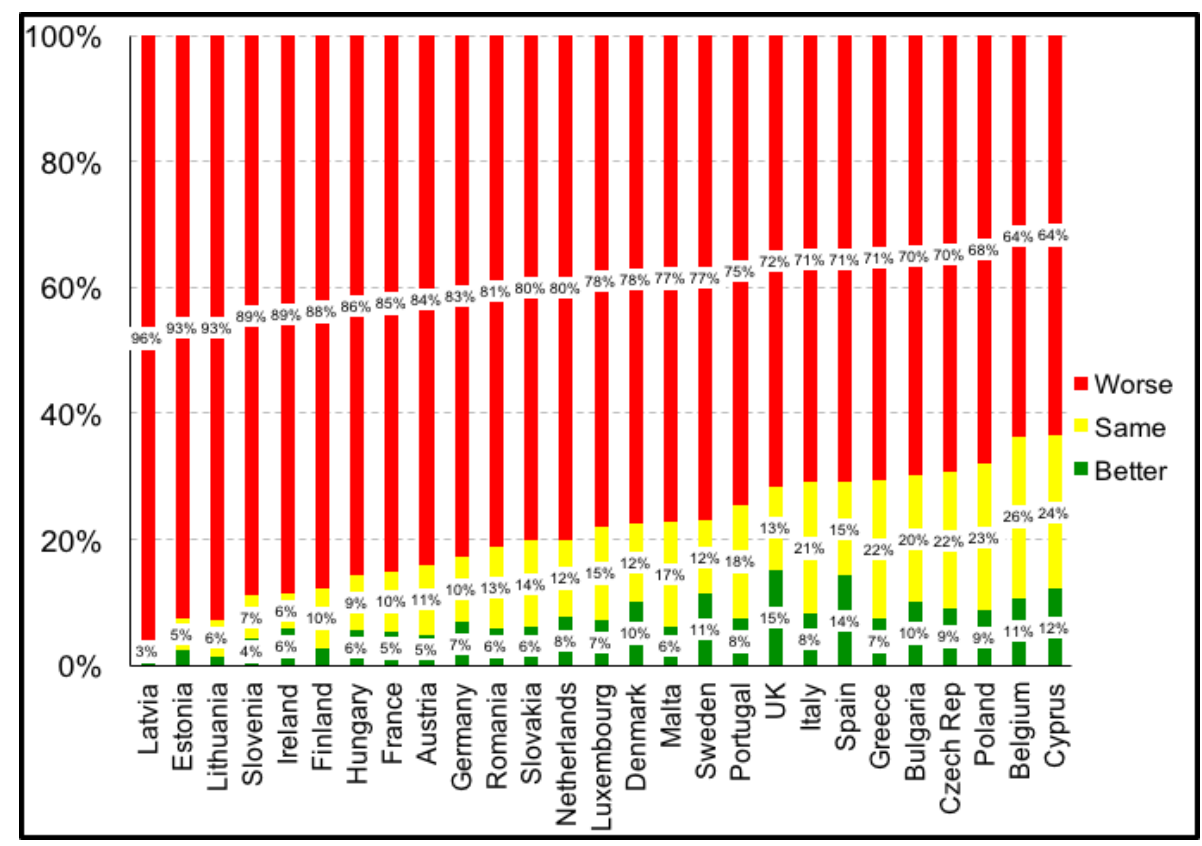

Figure 1. Perceptions of the economy by country in 2009 (\%). Source: van Egmond, van der Brug, Hobolt, Franklin, \& Sapir, 2013. Note: Data ordered by proportion of respondents saying "worse". 


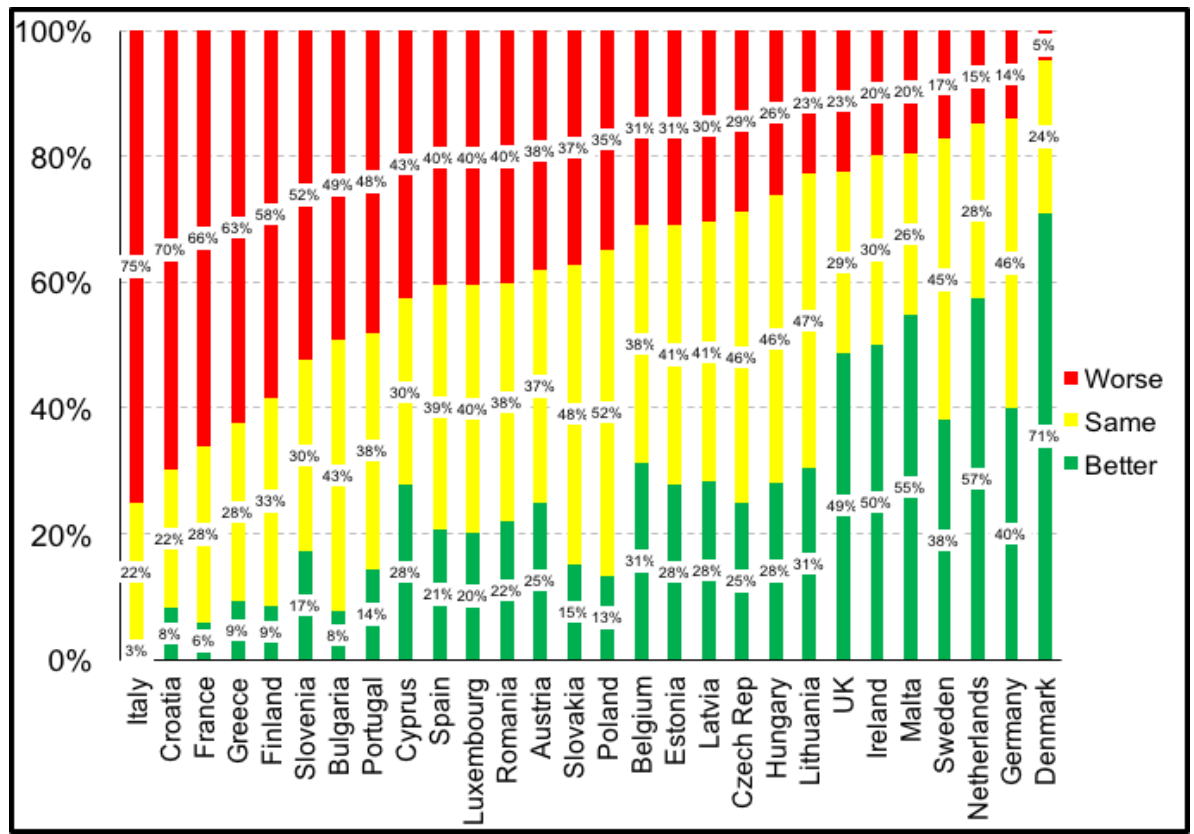

Figure 2. Perceptions of the economy by country in 2014 (\%). Source: Schmitt, Popa, \& Devinger, 2015. Note: Data ordered by proportion of respondents saying "worse".

The second critique is our focus on attributions of responsibility by voters. Critics suggest they might be contaminated by pre-existing political views (e.g. Bisgaard, 2015; Tilley \& Hobolt, 2011). An alternative strategy might have been to look at responsibility delineation from an aggregate perspective using an index based on institutional criteria including a country's electoral and party system, majority status of government, and opposition influence, as previous work has done (e.g. Anderson, 2000; Powell Jnr. \& Whitten, 1993). However, this assumption requires us to believe voters have detailed information as to how the political system operates and where the responsibility for power really lies, which is debatable. In any event and in the vein of many other studies (e.g.: Hobolt \& Tilley, 2014; Marsh \& Tilley, 2009; Sanders, 2000), we believe subjective perceptions are key. Controlling for the respondent's ideological distance from the ideological position of the party of the incumbent head of government on the left-right scale circumvents this problem to an extent. Further, we are buoyed by Lavine, Johnston and Steenbergen's (2012) work showing ambivalent partisans-voters who can suspend their partiality, do exist, and that these voters judge based on evidence. We also know suspension of partisanship is all the more likely to occur when there is sizeable consensus on an issue, such as a severe economic crisis (Parker-Stephen, 2013; Stanig, 2013) or when economic conditions are improving. Thus, while we accept that our measure is not ideal and thus a caveat to our conclusions, we are confident the issue is not as problematic as might first appear.

In sum, our expectations can be summarized as follows:
$\mathrm{H} 1$ : Economic assessments will directly influence vote choice in the 2009 EP elections.

$\mathrm{H} 2$ : Voter attributions of responsibility to the national government for economic performance will condition the impact of economic assessments on vote choice in the 2014 EP elections.

We also expect the impact of the economy on vote choice in 2014 to vary by country. Specifically, we assume economic voting might differ between bailout and non-bailout countries. We classify 'bailout' countries as EU member states that received external financial assistance to avert sovereign defaults between 2008 and 2012. Eight states fall into this category: Cyprus, Greece, Hungary, Ireland, Latvia, Portugal, Romania and Spain. ${ }^{3}$ Our supposition is the economic crises in bailout countries have been markedly worse compared to nonbailout countries and the consequences felt much more profoundly, especially as bailout countries were subject to much more stringent austerity measures, with their government's economic decisions were under external scrutiny from institutions like the EU and the IMF.

Table 1 contrasts the positions of the two sets of countries on four prominent indicators of economic

\footnotetext{
${ }^{3}$ Our choice is based on those countries that received any EU/IMF financial assistance. Italy, although often considered as party of this group, was not officially in receipt of a formal bailout. An advantage of our classification is that we incorporate all member states adjudged to be in such financial peril that they needed external financial assistance, and not concentrated solely on the states of Southern Europe, which have received most scholarly attention to date (e.g. Lewis-Beck \& Nadeau, 2012; Schmitt \& Teperoglou, 2015).
} 
performance for the year 2014. As we can see, the eight countries who received external financial assistance performed significantly worse on average on three indicators: unemployment, youth unemployment, and government debt as a percentage of GDP. Only for economic growth are the bailout and nonbailout countries similar in performance. But if we remove the extreme outlier among the bailout countries for 2014, namely Ireland which recorded economic growth of $5.2 \%$ in 2014 , the difference is much greater (1.34\% growth for bailout countries versus $1.93 \%$ for non-bailout countries). In sum, there is clear evidence to suggest sizeable differences in economic performance between the two sets of countries and this might play into how economics influenced vote in the 2014 EP elections. Thus we suggest that:

H3: Economic assessments and voter attributions of responsibility for economic performance will have a greater impact on vote choice in the $2014 \mathrm{EP}$ elections in countries that have received bailouts from external bodies compared to those who have not.

Table 1. Selected economic conditions in bailout versus non-bailout countries in 2014.

\begin{tabular}{lrc}
\hline & Bailout & Non-Bailout \\
\hline Unemployment & $15.43 \%$ & $8.55 \%$ \\
Youth unemployment & $33.41 \%$ & $19.39 \%$ \\
Economic growth & $1.83 \%$ & $1.93 \%$ \\
General Government Gross & $97.58 \%$ & $62.96 \%$ \\
debt as a percentage of GDP & & \\
\hline
\end{tabular}

Note: Authors' calculations based on classification of bailout versus non-bailout countries on data gathered from Eurostat and World Bank.

\section{Research Strategy}

\subsection{Data and Primary Variable Classifications}

Our data comes from the 2009 (van Egmond, van der Brug, Hobolt, Franklin, \& Sapir, 2013) and 2014 (Schmitt, Popa, \& Devinger, 2015) European Electoral Studies (EES), two cross-sectional comparative postelection surveys administered in all EU member states. The data includes identical questions posed to respondents that tap voters' assessments of the economy, who they perceive to be responsible for it, as well as other relevant political and demographic variables.

Our dependent variable is binary and captures whether a respondent voted for the national governing party/coalition (coded 1) or another party/coalition (coded 0 ) on the basis of the question: "Which party did you give your vote to in these recent European Parliament elections?" Respondents who reported ab- staining were excluded from the analysis. ${ }^{4}$

We have two primary independent variables. The first is perceptions of economic performance. Our measure is sociotropic and retrospective and is based on the question: "Compared to 12 months ago, do you think that the general economic situation in [our country] is..." In common with previous studies of economic voting, we recoded this measure into a binary variable, with a 1 capturing those who rated the economy as "Is a lot better" and "Is a little better" and 0 representing respondents who said "Is a little worse" and "Is a lot worse". ${ }^{5}$ Our second independent variable of interest is responsibility attribution for the national economy. We capture this with responses to the question: "thinking about the economy, how responsible is [incumbent] government for economic conditions in [our country]". We refer to this as perceptions of economic responsibility (PER), which is scaled from 0 to 10 , with a score of 0 indicating a voter does not hold the government responsible for the economy and a score of 10 representing voters who deemed the government fully responsible.

Our total $\mathrm{N}$ at the micro level across the two election cycles is 26,728 observations: 19,878 for the 2009 elections and 6,850 for the 2014 EP elections, with all country samples across both waves having a minimum of 1,000 initial observations and being representative of the national population. The difference in number of observation between 2009 and 2014 sample is a result of fewer observations available in 2014 and due to our classifications. ${ }^{6}$ Our macro observations are 27 for both elections. $^{7}$

\footnotetext{
${ }^{4}$ For robustness, we re-classified our dependent variable to include the party of the incumbent Head of Government. We identified no substantive deviations, with the alternative models in line with our theoretical expectations. The alternative specifications are detailed in Table A7 in Appendix.

${ }^{5}$ Respondents who answered "stayed the same" and "don't know" were excluded from the analysis. For robustness, we reclassified this variable by including those who responded "stayed the same" in both the "worse" and the "better" categories and re-estimating our models on this basis (see Tables A5 and A6 in Appendix). Regarding the inclusion of "stayed the same" in the "worse" category, which we argue is the most appropriate specification given the economic crisis, we identified no substantive deviations, with the alternative models in line with our theoretical expectations. When the "stayed the same" is included among the "better" category, we do see that the coefficient for the interaction term in 2014 is statistically significant only at $p<0.1$. While a slight deviation on our reported analysis, it does not go against our theoretical expectations.

${ }^{6}$ This is a result of the many respondents who answered that economy "stayed the same" in 2014 Also, a larger number of respondents refused to answer for which party they gave their vote in 2014 EP election.

${ }^{7}$ Croatia is excluded from the analysis to maintain comparability at the macro level as the country only became a member of the EU in 2013 and thus only participated in the 2014 elections.
} 


\subsection{Modelling Strategy and Covariate Selection}

The hierarchical nature of the EES data calls for a multilevel strategy. When observations within a sample are clustered, the data violates the assumption of independence of observations. Failure to take account of this could result in the incorrect estimation of standard errors, which can increase the probability of Type-l errors (Gelman \& Hill, 2007). Multilevel modeling allows us to estimate separate variance components for both the micro and macro levels. For this study, we define two levels of analysis: citizens (micro-level) that are nested in countries (macro-level). ${ }^{8}$ We estimate multilevel models with random effects for country and economy, as we expect the impact of economy will vary between countries.

We face difficulties in taking a multilevel approach in testing H3: the difference between bailout and nonbailout countries in terms of economy's impact on vote in the 2014 elections. With bailout countries only accounting for eight observations, a multilevel approach is infeasible because multilevel models with an inadequate number of macro observations have been noted for producing biased estimates (e.g.Maas \& Hox, 2004; Stegmueller, 2013). One might assume we would circumvent this by estimating a multilevel (or indeed simple logit) model by just including a three-way interaction in our model. However, given the noted difficulties in interpreting interactions in logit models (Brambor, Roberts Clarke, \& Golder, 2006), we suggest a threeway interaction is too convoluted and a more comprehensive interpretation is achieved from this strategy. Accordingly, Models V and VI in Table 3 are based on regular logit models with robust standard errors.

The remainder of our model is based on the wellestablished specification for testing economic effects in a comparative analysis (e.g. Duch \& Stevenson, 2008; Lewis-Beck \& Nadeau, 2012). Therefore, we control for religious service attendance as a proxy of cleavage and ideology. Our ideological measure captures the ideological distance of the respondent from the ideological position of the party of the incumbent head of government on the left-right scale. ${ }^{9}$ To this, we add the in-

For robustness, each model was re-estimated omitting each individual country to establish if a specific country was driving our results. We identified no substantive deviations, with the alternative models in line with our theoretical expectations.

${ }^{8}$ We also estimated our models in the classic pooled analysis fashion and we identified no substantive deviations from our theoretical expectations.

${ }^{9}$ We calculated ideology-distance variable as follows: we took the mean of respondents' placements of the head of government party on a left-right scale for each country and each election. Then we subtracted this mean from the individual respondent's self-placement on the left-right scale and took the absolute value of the results, which created the ideological distance variable. teraction term ${ }^{10}$ between economic evaluations and perceptions of government responsibility in line with our theoretical expectations, to arrive at the following model:

Vote $=f($ Cleavage, ideological distance, economy * perceptions of government responsibility)

Summary statistics for each variable are included in the appendix (see Tables A2-A4).

\section{Empirical Analysis}

Our empirical analysis consists of three parts. First we are interested in establishing the direct effect of evaluations of the economy on vote choice. Models I (2009) and II (2014) of Table 2 test this. Second we add an interaction component to the basic model to test our second hypothesis-our expectation being the impact of the economy on vote might be mediated by how much responsibility is attributed to the national government for economic performance. We expect to observe heterogeneity between the elections-i.e. perceptions of economic responsibility will mediate the impact of economy on vote in 2014 but not in 2009. Models III (2009) and IV (2014) of Table 2 investigates this. Third, we explore whether the impact of economy and responsibility attribution is the same in 2014 between countries. We assume different effects will take hold in bailout compared to non-bailout states, with economy and the interaction between economy and responsibility attribution having a stronger impact in bailout states. We test this in Models V (bailout) and VI (non bailout) of Table 3.

In models I and II of Table 2, we see the economy variable is positive and statically significant in both models $(p<0.01)$. This suggests that for respondents who judge the economy has improved in their country in the preceding twelve months before the election, the likelihood of voting for the government increased substantially. Such an effect is hardly surprising and confirms the potency of economics in shaping vote, even in a second-order election like the EP elections.

\footnotetext{
${ }^{10}$ It should be noted that the magnitude and statistical significance of interaction effects in models with binary dependent variables can vary by observation (Ai \& Norton, 2003). As a robustness check, we estimated the interaction effects following Norton, Wang and Ai (2004) and observed no significant deviations from our reported analysis.
} 
Table 2: Multilevel logit models examining the impact of economic voting in 27 democracies. Source: van Egmond, van der Brug, Hobolt, Franklin, \& Sapir, 2013; Schmitt, Popa, \& Devinger, 2015.

\begin{tabular}{|c|c|c|c|c|}
\hline $\begin{array}{l}\text { Dependent variable: Vote for the } \\
\text { Incumbent Party or Coalition }\end{array}$ & $\begin{array}{c}(1) \\
2009\end{array}$ & $\begin{array}{c}\text { (II) } \\
2014\end{array}$ & $\begin{array}{c}(I I I) \\
2009\end{array}$ & $\begin{array}{l}\text { (IV) } \\
2014\end{array}$ \\
\hline \multicolumn{5}{|l|}{ FIXED EFFECTS } \\
\hline \multirow[t]{2}{*}{ Economy } & $0.712 * *$ & $1.191^{* *}$ & $0.796 * *$ & $0.688^{*}$ \\
\hline & $(0.113)$ & $(0.209)$ & $(0.18)$ & $(0.268)$ \\
\hline \multirow[t]{2}{*}{ PER } & - & - & $-0.036 * *$ & $-0.039 * *$ \\
\hline & & & $(0.007)$ & $(0.015)$ \\
\hline \multirow[t]{2}{*}{ Ideology-distance } & $-0.271 * *$ & $-0.055 * *$ & $-0.273 * *$ & $-0.057 * *$ \\
\hline & $(0.01)$ & $(0.014)$ & $(0.011)$ & $(0.014)$ \\
\hline \multirow[t]{2}{*}{ Religion } & $-0.114 * *$ & $-0.05^{*}$ & $-0.118 * *$ & $-0.048^{*}$ \\
\hline & $(0.012)$ & $(0.021)$ & $(0.013)$ & $(0.021)$ \\
\hline \multirow[t]{2}{*}{ Economy x PER } & - & - & -0.014 & $0.066 * *$ \\
\hline & & & $(0.021)$ & $(0.022)$ \\
\hline \multirow[t]{2}{*}{ Constant } & -0.08 & $-0.424^{*}$ & 0.202 & -0.131 \\
\hline & $(0.129)$ & $(0.181)$ & (0.139) & $(0.213)$ \\
\hline \multicolumn{5}{|l|}{ RANDOM EFFECTS } \\
\hline \multirow[t]{2}{*}{ (Intercept) Country } & 0.233 & 0.051 & 0.234 & 0.056 \\
\hline & $(0.483)$ & $(0.225)$ & $(0.484)$ & $(0.237)$ \\
\hline \multirow[t]{2}{*}{ (Intercept) Economy by Country } & 0.119 & 0.521 & 0.115 & 0.511 \\
\hline & $(0.345)$ & $(0.722)$ & (0.339) & $(0.715)$ \\
\hline N (Micro/Macro) & $19878 / 27$ & $6850 / 27$ & $19498 / 27$ & $6790 / 27$ \\
\hline Log Likelihood & -10254.8 & -4229.7 & -10025 & -4185.8 \\
\hline $\mathrm{AIC}$ & 20521.7 & 8471.3 & 20066 & 8387.6 \\
\hline $\mathrm{BIC}$ & 20569.1 & 8512.3 & 20129 & 8442.2 \\
\hline
\end{tabular}

Note: Standard error in parenthesis; ${ }^{*} p<0.05 ;{ }^{* *} p<0.01$.

Table 3 Logit models examining the impact of economic voting in 27 democracies in the 2014 European Parliament elections. Source: Schmitt, Popa, \& Devinger, 2015.

\begin{tabular}{lcc}
\hline $\begin{array}{l}\text { Dependent variable: Vote for the } \\
\text { Incumbent Party or Coalition }\end{array}$ & $\mathbf{( V )}$ & $\begin{array}{c}\text { (VI) } \\
\text { 2014 (Non bailout) }\end{array}$ \\
\hline Economy & $\mathbf{2 0 1 4}$ (Bailout) & -0.062 \\
& 0.402 & $(0.19)$ \\
PER & $(0.344)$ & -0.02 \\
& $-0.132^{* *}$ & $(0.015)$ \\
Ideology-distance & $(0.029)$ & $-0.093^{* *}$ \\
& 0.001 & $(0.014)$ \\
Religion & $(0.028)$ & -0.028 \\
& $-0.138^{* *}$ & $(0.02)$ \\
Economy x PER & $(0.038)$ & $0.078^{* *}$ \\
Constant & $0.137^{* *}$ & $(0.023)$ \\
N & $(0.041)$ & 0.118 \\
Log Likelihood & 0.545 & $(0.154)$ \\
AIC & $(0.3)$ & 5078 \\
\hline
\end{tabular}

Note: Robust standard error in parenthesis; ${ }^{*} p<0.05 ;{ }^{*} p<0.01$.

However, our supposition is the 'true impact' of economy only reveals itself when perceptions of responsibility for economic performance (PER) are accounted for. Therefore, we add an interaction term to our models. We detail the results in models III and IV of Table 2 . It is evident that the inclusion of responsibility attribution and the interaction with economic assessments results in some important changes. First, PER on its own has an influence in both elections. In both 2009 and 2014, the more citizens thought the economy was the responsibility of the government, the more likely they were to vote against the government, hardly surprising given the economic circumstances in many states. Second, the strong direct effect of economic perceptions on vote persists: the more voters thought the economy was performing well (incidentally few did), the more likely 
they were to vote for the incumbent administration, and this effect remains independent of responsibility attribution. However, the interaction term in 2009 does not reach statistical significance. ${ }^{11}$ This is in line with our expectations-economic perceptions were the primary driver of economic voting in the 2009 poll.

We see a different pattern for 2014 (Model IV). Here, the addition of attributions of responsibility results in the direct impact of the economy reaching statistical significance at $p<0.05$ level and still having a positive impact. However, the interaction term is positive and significant implying the impact of the economy is conditioned by voter perceptions of responsibility attribution. When the economy was considered to be doing well and the government were perceived to be re-

11 We were conscious that the magnitude and statistical significance of interaction effects in models with binary dependent variables can vary by observation. For robustness, we reestimated the interaction using Ai and Norton's (2003) approach and found that the significance levels and sign of the coefficients to be in same direction as those detailed in our analysis. sponsible for it, voters were more likely to have supported the incumbent administration. To gain an idea of the magnitude of this effect, Figure 3 (for the 2009 EP election) and Figure 4 (for the 2014 EP election) plots the interaction effect between economy and perception of economic responsibility. Looking at Figure 4, the upper right plot indicates that when perception of economic responsibility is at the highest level, the probability to vote for incumbent government is around 60 percent for respondents who thought that the economy has improved in the last 12 months prior to the election. Yet, for those respondents who were more sceptical about the economy, the probability to vote for the governing party or coalition drops to around 30 percent. However, this difference is not so evident when the perception of economic responsibility is at its lowest (bottom left plot Figure 4). Here the probability to vote for the incumbent party between those respondents who answered that economy was better was approximately 50 percent compared to those who believed that the economy was worse in the past 12 months (approximately 40\%).

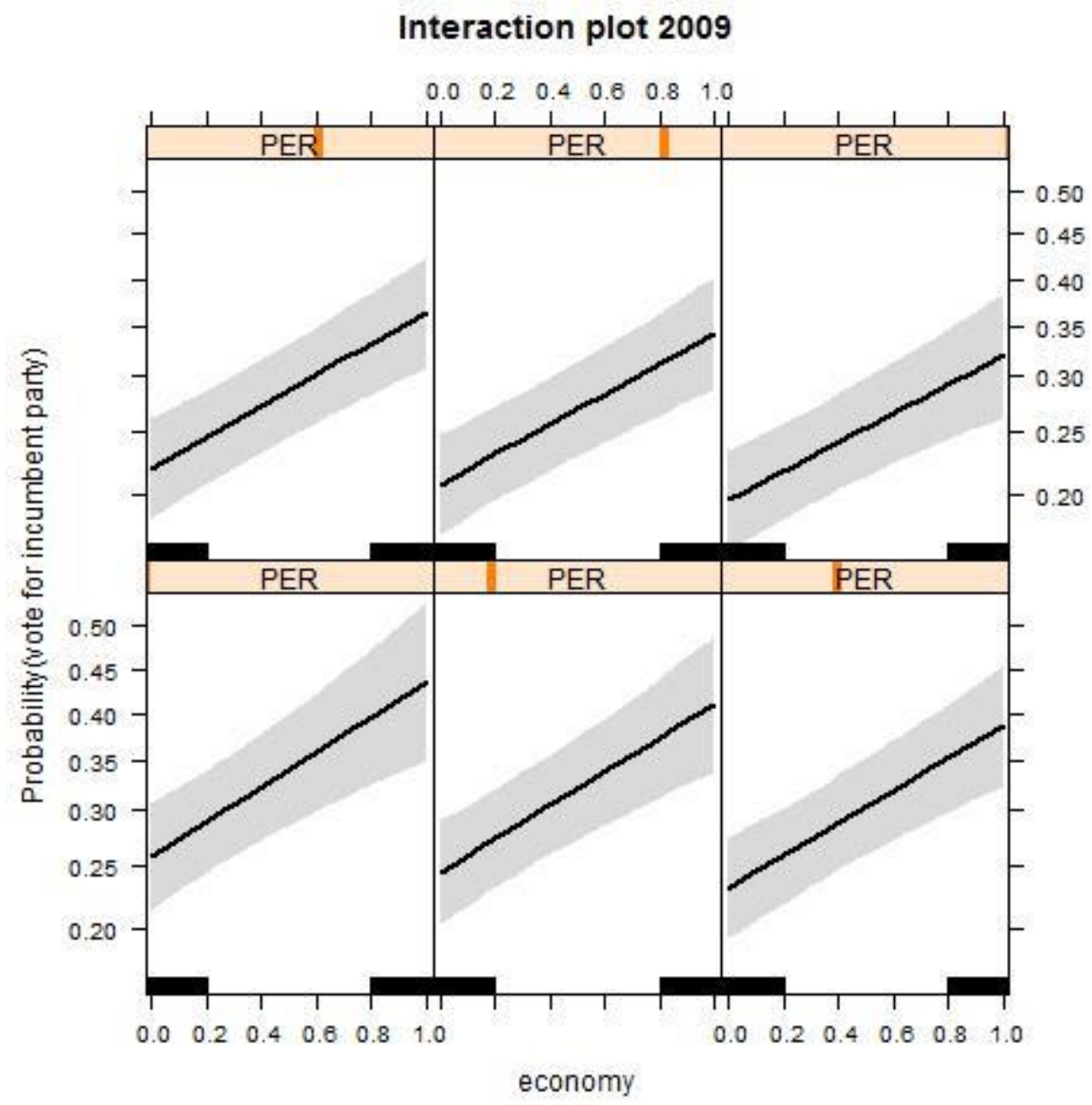

Figure 3. Interaction effect plots between economy and PER for 2009 EP election. Note: The upper right plot indicates that PER is at the highest level. The lower left plot indicates that PER is at the lowest level. 


\section{Interaction plot 2014}

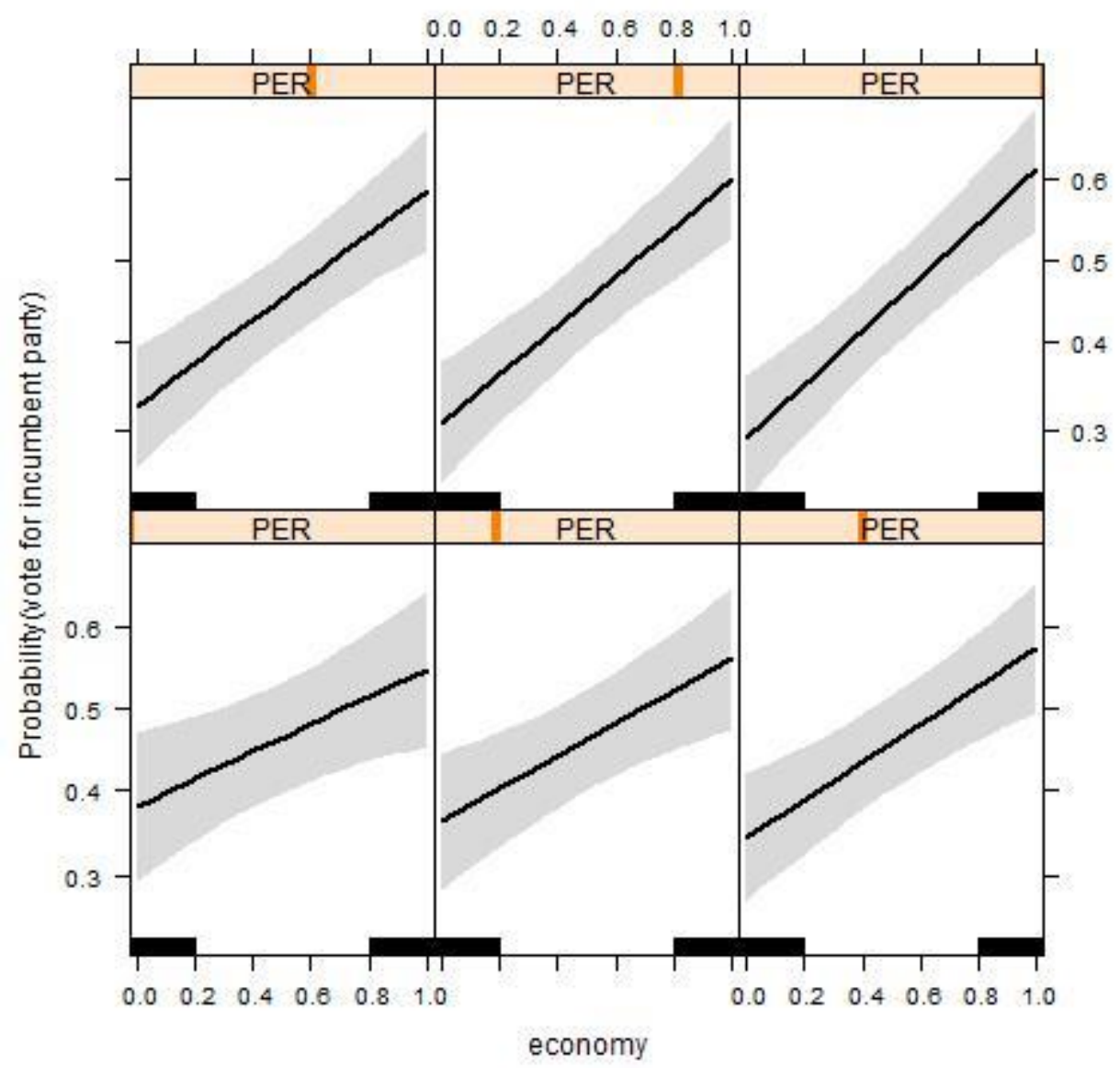

Figure 4. Interaction effect plots between economy and PER for 2014 EP election. Note: The upper right plot indicates that PER is highest. The lower left plot indicates that PER is at the lowest level.

In sum, we deduce the following from our analysis. There is support for $\mathrm{H} 1$ - the economy had a direct impact on vote choice in 2009. Voter assessments of the economy were enough to influence vote choice with those perceiving the economic situation to be good voting for the incumbent administration and those classifying it as worse voting against it. While economics also mattered in 2014, its impact on vote was conditioned by how much responsibility voters credited to the government for economic performance, with the more responsibility assigned to the government and the better the economic circumstances, the more likely voters were to vote for the government. The key point though is the direct effect of economy in 2014 was partially channelled through responsibility ascriptions, providing support for $\mathrm{H} 2$.

Regarding the impact of the economy and responsibility attribution on vote in 2014, we anticipated this effect may not be universal across the EU bloc but that it might have differed across countries dependent on whether a state had received a bailout or not. To test this, we divided our sample into 'bailout' and 'nonbailout' countries and devised two separate logit models to explore the differences between the two sets of nations. We expect in countries that have received a financial support from the EU/IMF, we will observe a greater level of economic responsibility: the perceptions of responsibility will have a stronger and negative effect on vote compared to non-bailout countries. This is because the economic situation in bailout countries was much worse compared to the non-bailout countries. Therefore, we would expect that the attribution of responsibility for the economic circumstances would have larger negative effect on the incumbent government among bailout countries.

Our results are detailed in Models $\mathrm{V}$ and $\mathrm{VI}$ of Table 3. Perceptions of the state of the economy do not have a significant effect on the vote in either set of countries, which fits with our overall theoretical argument that economic voting in 2014 was channelled through perceptions of responsibility. Instead, the differences between the two sets of countries are seen with respect to the impact of perceptions of responsibility and perceptions of responsibility when interacted with economic assessments. First, attribution of responsibility on its own had a significant effect in bailout countries-when governments were held responsible for the performance of the national economy, voters were 
more likely to vote against it. However, we do not have evidence of the same effect taking hold in non-bailout countries. We suggest this significant difference reflects the poorer state of bailout countries' economies.

The interaction effect in both models is positive and significant which is line with our expectations-the better the economy is and the more governments are considered to be responsible, the greater the likelihood of voting for the incumbent government. We conclude there is support for H3: voters in bailout countries approached the 2014 elections differently to the nonbailout. First and foremost, attribution of responsibility on its own mattered in these countries, while it did not in non-bailout states. Further, the impact of the economy was conditioned on this basis but also was shown to be stronger in bailout countries than non-bailout countries. Our overall results show that economic voting is present in both the 2009 and 2014 EP elections. However, this does mask clear differences as to how economic voting shaped vote choice between the two elections and cross-nationally.

\section{Discussion and Conclusion}

While much ink has been spilt exploring the influence of economy on the vote in national elections and referendums, and on attitudes towards European integration, few studies have analysed the effect of economic perceptions on vote in European Parliament elections. Yet the onset of the Global Financial Crisis (GFC), its domination of the political agenda over the past seven years, and the fact its marked effects are still very much felt, calls for a re-assessment. Our contribution explores the economy's impact in the 2009 and 2014 contests respectively.

Our study shows that like other elections, citizens' views about the economy do influence their vote in European elections. This is somewhat contrary to the conclusions of Tilley et al. (2008), who found minimal evidence for economic voting, and argued that existing political preferences contaminate economic perceptions. In a cross-sectional sample, endogeneity is difficult to rule out but we are confident that convincing evidence has been presented which shows that even when endogenous concerns can be conclusively addressed, economic voting exists. Accordingly, we suggest the differences in our findings compared to theirs are best explained by the different contexts. The Global Financial Crisis and its profound implications on citizens have ensured economics has been front and centre of the political agenda for the past seven years. As such, it became the central preoccupation of citizens and this translated into it becoming more important in shaping vote choice at the European level.

However, in line with previous scholarship which has found economic voting depends on context (e.g. Anderson 2000; Powell Jnr. \& Whitten 1993), we found economics shaped vote in different ways across the two elections. In 2009, with the GFC in its infancy, and its consequences becoming gradually apparent, voters, many of whom were getting their first opportunity to go to the ballot box since the eruption of the crisis, were directly motivated by their perceptions of how the economy was performing. In 2014, economic perceptions still mattered. However, voter calculus shifted and the potency of economic voting depended on how much responsibility voters assigned to the national government for economic performance. The more responsibility they felt the government had, the more likely economic voting was to take hold. These assessments were seen to be stronger in countries that had received external financial assistance in the preceding six years, hardly surprising considering the GFCs impact on these states was more manifest than others. This underlines that economic voting, while prevalent in the European context, is conditional both on time and space. It also suggests that voters' response to economic crisis evolves, with economic perceptions initially enough to shape vote choice, but as time goes on, economic voting becomes motivated by other considerations including who is deemed to be responsible for the circumstances.

Our study also cast doubt on the idea that the 2014 European elections were much different compared to EP elections of the past, in spite of the characterisation of 'This time it's different' (see Hobolt, 2014). For one thing, economics mattered in both elections, albeit differently. But more fundamentally, voters in both remained strongly motivated by national considerations with domestic issues such as national economic perceptions playing a key role. Therefore, we can deduce the EP elections remain classic 'second-order' contests (for similar conclusions see Quinlan \& Okolijk, 2016; Schmitt \& Teperoglou, 2015).

Interesting avenues of research remain. While our study has focused on voters' ascriptions of economic responsibility to national governments, the attributions voters ascribe to the European Union remains underdeveloped (an exception is Costa-Lobo \& Lewis-Beck, 2012). Additionally, economic voting is multidimensional. Here we have concentrated on the conventional valence reward-punishment model but other dimensions merit exploration. Gaining traction is the idea that there is a patrimonial aspect to economic voting with citizens' wealth has been found to shape voter preferences in Denmark, France, and Portugal (e.g. Costa-Lobo, 2013; Stubager, Lewis-Beck, \& Nadeau, 2013). Given its existence at the national level, it might be that patrimony also influences voters in European contests and future studies should explore this.

\section{Acknowledgements}

We wish to thank Johan A. Elkink, Wouter van der 
Brug, Claes de Vreese, Katja Gatterman, attendees at the Final Conference of the 2014 European Election Study, held in Mannheim, Germany (6-7 November 2015), as well as two anonymous reviewers for their helpful comments and suggestions. All remaining errors are our own responsibility.

\section{Conflict of Interests}

The authors have no conflicts of interest to declare.

\section{References}

Ai, C., \& Norton, E. C. (2003). Interaction terms in logit and probit models. Economic Letters, 80(1), 123-129.

Anderson, C. (2000). Economic voting and political context: A comparative perspective. Electoral Studies, 19(2), 151-70.

Anderson, C. (2007). The end of economic voting? Contingency dilemmas and the limits of democratic accountability. Annual Review of Political Science, 10, 271-96.

Ashworth, S., \& Bueno de Mesquita, E. (2008). Electoral selection, strategic challenger entry, and the incumbency advantage. Journal of Politics, 70, 1006-1025.

Bartels, L. (2002). Beyond the running tally: Partisan bias in political perceptions. Political Behaviour, 24, 117150.

Bisgaard, M. (2015). Bias will find a way: Economic perceptions, attributions of blame, and partisanmotivated reasoning during crisis. Journal of Politics, 77(3), 849-860.

Brambor, T., Roberts Clarke, W., \& Golder, M. (2006). Understanding interaction models: Improving empirical analyses. Political Analysis, 14, 63-82.

Clarke, H. D., Sanders, D., Stewart, M., \& Whiteley, P. (2009). Performance politics and the British voter. Cambridge: Cambridge University Press.

Cordero, G., \& Montero, J. R. (2015). Against bipartyism, towards dealignment? The 2014 European elections in Spain. South European Society and Politics, 20(3), 357-379.

Costa-Lobo, M., \& Lewis-Beck, M. S. (2012). The integration hypothesis: How the European Union shapes economic voting. Electoral Studies, 31, 522-528.

Costa-Lobo, M. (2013). Dimensions of the economic vote: Valence, positional, and patrimony voting in Portugal's 2011 elections. Electoral Studies, 32(3), 460-464.

Dalton, R. J. (2006). Citizen politics: Public opinion and political parties in advanced industrial democracies (4th ed.). Washington D.C.: CQ Press.

Dassonneville, R., \& Lewis-Beck, M. S. (2014). Macroeconomics, economic crisis and electoral outcomes: A national European pool. Acta Politica, 49, 372-394.

de Vries, C., Edwards, E., \& Tilman, E. R. (2011). Clarity of responsibility beyond the pocketbook: How political institutions condition EU issue voting. Comparative Political Studies, 44(3), 339-363.

de Vries, C., van der Brug, W., van Egmond, M. H., \& van der Eijk, C. (2011). Individual contextual variation in EU issue voting: The role of political information. Electoral Studies, 30(1), 16-28.

Doyle, O., \& Fidrmuc, J. (2006). Who favors enlargement? Determinants of support for EU membership in the candidate countries' referenda. European Journal of Political Economy, 22(2), 520-543.

Duch, R., \& Stevenson, R. (2008). The economic vote: How political and economic institutions condition election results. Cambridge, MA: Cambridge University Press.

Eichengreen, B. (2013, September 12). Eurozone collapse has been avoided but a hard landing is still possible. The Guardian. Retrieved from http://www. theguardian.com/business/2013/sep/12/eurozonecollapse-avoided-hard-landing

Elkink, J. A., Quinlan, S., \& Sinnott, R. (2015). Economic voting and EU referendums: Sociotropic versus pocketbook voting in the 2008 and 2009 Lisbon Treaty referendums in Ireland (Working Paper). Dublin: University College Dublin.

Evans, G., \& Anderson, R. (2006). The political conditioning of economic perceptions. Journal of Politics, 68, 194-207.

Fraile, M., \& Lewis-Beck, M. S. (2013). Multi-dimensional economic voting in Spain: The 2008 election. Electoral Studies, 32(3), 465-469.

Fraile, M., \& Lewis-Beck, M. S. (2014). Economic vote instability: Endogeneity or restricted variance? Spanish panel evidence from 2008 and 2011. European Journal of Political Research, 53, 160-179.

Gabel, M. (1998). Economic integration and mass politics: Market liberalization and public attitudes in the European Union. American Journal of Political Science, 42(3), 936-953.

Gelman, A., \& Hill, J. (2007). Data analysis using regression and hierarchical/multilevel models. Cambridge: Cambridge University Press.

Gordon, S. C., \& Huber, G. A. (2007). Challenger entry and voter learning. American Political Science Review, 101, 303-320.

Hellwig, T., \& Coffey, E. (2011). Public opinion, party messages, and responsibility for the financial crisis in Britain. Electoral Studies, 30, 417-426.

Hix, S. (2013). Why the 2014 European elections matter: Ten key votes in the 2009-2013 European Parliament. European Policy Analysis: The Swedish Institute for European Policy Studies, (2013:15epa). Retrieved from www.sieps.se/sites/default/files/2013_ 15epa.pdf

Hix, S., \& Marsh, M. (2011). Second-order effects plus pan-European political swings: An analysis of European Parliament elections across time. Electoral Studies, 30(1), 4-15. 
Hobolt, S. B. (2014). A vote for the President? The role of Spitzenkandidaten in the 2014 European Parliament elections. Journal of European Public Policy, 21(10), 1528-1540.

Hobolt, S. B., \& Spoon, J. (2012). Motivating the European voter: Parties, issues, and campaigns in European Parliament elections. European Journal of Political Research, 51, 701-727.

Hobolt, S. B., \& Tilley, J. (2014). Who's in charge? How voters attribute responsibility in the European Union. Comparative Political Studies Comparative Political Studies, 47(6), 795-819.

Hotten, R. (2011, June 21). Greece takes the eurozone's future to the brink. $B B C$ News. Retrieved from http://www.bbc.com/news/business-13842763

Kayser, M. A., \& Peress, M. (2012). Benchmarking across borders: Electoral accountability and the necessity of comparison. American Political Science Review, 106(3), 661-684.

Lavine, H. G., Johnston, C. D., \& Steenbergen, M. R. (2012). The ambivalent partisan: How critical loyalty promotes democracy. Oxford: Oxford University Press.

LeDuc, L., \& Pammett, J. H. (2013). The fate of governing parties in times of economic crisis. Electoral Studies, 32, 494-499.

Lewis-Beck, M. S., \& Nadeau, R. (2012). PIGS or not? Economic voting in Southern Europe. Electoral Studies, 31, 472-477.

Lewis-Beck, M. S., Nadeau, R., \& Elias, A. (2008). Economics, party, and the vote: Causality issues and panel data. American Journal of Political Science, 52(1), 84-95.

Lewis-Beck, M. S., Nadeau, R., \& Foucault, M. (2013). The compleat economic voter: New theory and British evidence. British Journal of Political Science, 43(2), 241-261.

Lewis-Beck, M. S., \& Paldam, M. (2000). Economic voting: An introduction. Electoral Studies, 19(2), 113121.

Lewis-Beck, M. S., \& Stegmaier, M. (2013). The VPfunction revisited: A survey of the literature on vote and popularity functions after over 40 years. Public Choice, 157, 267-285.

Maas, C., \& Hox, J. (2004). The influence of violations of assumptions on multilevel parameter estimates and their standard errors. Computational Statistics and Data Analysis, 46(3), 427-440.

Marsh, M. (1998). Testing the second-order election model after four European elections. British Journal of Political Science, 28(4), 591-607.

Marsh, M., \& Mikhaylov, S. (2014). A conservative revolution: The electoral response to economic crisis in Ireland. Journal of Elections, Public Opinion, and Parties, 24(2), 160-179.

Marsh, M., \& Tilley, J. (2009). The attribution of credit and blame to governments and its impact on vote choice. British Journal of Political Science, 40, 115134.

Nannestad, P., \& Paldam, M. (1994). The VP-function: A survey of the literature on vote and popularity functions after 25 years. Public Choice, 79, 213-245.

Nezi, R. (2012). Economic voting under the economic crisis: Evidence from Greece. Electoral Studies, 31(3), 498-505.

Nezi, R., \& Katsanidou, A. (2014). From valence to position: Economic voting in extraordinary conditions. Acta Politica, 49, 413-430.

Norton, E. C., Wang, H., \& Ai, C. (2004). Computing interaction effects and standard errors in logit and probit models. Stata Journal, 4, 154-167.

Parker-Stephen, E. (2013). Tides of disagreement: How reality facilitates (and inhibits) partisan public opinion. Journal of Politics, 75(4), 1077-1088.

Powell Jnr., G. B., \& Whitten, G. D. (1993). A crossnational analysis of economic voting: Taking account of the political context. American Journal of Political Science, 37(2), 391-414.

Quinlan, S., \& Okolikj, M. (2016). This time it's different...but not really: The 2014 European Parliament elections in Ireland. Irish Political Studies. doi: 10.1080/07907184.2016.1151415

Reif, K., \& Schmitt, H. (1980). Nine second-order national elections: A conceptual framework for the analysis of European election results. European Journal of Political Research, 8(1), 3-44.

Sanders, D. (2000). The real economy and the perceived economy in popularity functions: How much do the voters need to know? A study of British data 19741997. Electoral Studies, 19(2), 275-294.

Schmitt, H. (2005). The European Parliament elections of June 2004: Still second-order? West European Politics, 28(3), 650-679.

Schmitt, H., Popa, S. A., \& Devinger, F. (2015). European Parliament election study 2014, voter study, first post-election survey. GESIS Data Archive, Cologne. ZA5161 Data file Version 1.0.0. doi: 10.4232/1.5161

Schmitt, H., \& Teperoglou, E. (2015). The 2014 European Parliament elections in Southern Europe: Secondorder or critical elections? South European Society and Politics, 20(3), 287-309.

Singer, M. (2011). When do voters actually think "It's the economy"? Evidence from the 2008 presidential campaign. Electoral Studies, 30(4), 621-632.

Soroka, S. (2006). Good news and bad news: Asymmetric responses to economic information. Journal of Politics, 68, 372-385.

Stanig, P. (2013). Political polarization in retrospective economic evaluations during recessions and recoveries. Electoral Studies, 32(4), 729-745.

Stegmueller, D. (2013). How many countries for multilevel modelling? A Monte Carlo study comparing bayesian and frequentist approaches. American Journal of Political Science, 57(3), 748-761. 
Stubager, R., Lewis-Beck, M. S., \& Nadeau, R. (2013). Reaching for profit in the welfare state: Patrimonial economic voting in Denmark. Electoral Studies, 32, 438-444.

Tilley, J., Garry, J., \& Bold, T. (2008). Perceptions and reality: Economic voting at the 2004 European Parliament elections. European Journal of Political Research, 47, 665-686.

Tilley, J., \& Hobolt, S. B. (2011). Is the government to blame? An experimental test of how partisanship shapes perceptions of performance and responsibility. Journal of Politics, 73(2), 316-330.

Trieb, O. (2014). The voter says no but nobody listens: Causes and consequences of the Eurosceptic vote in the 2014 European elections. Journal of European Public Policy, 21(10), 1541-1554.

Tucker, J. A., Pacek, A. C., \& Berinsky, A. J. (2002). Transitional winners and losers: Attitudes toward EU membership in post-communist countries. American
Journal of Political Science, 46(3), 557-571.

van der Brug, W., van der Eijk, C., \& Franklin, M. (2007). The economy and the vote: Economic conditions and elections in fifteen countries. Cambridge: Cambridge University Press

van Egmond, M. H., van der Brug, W., Hobolt, S. B., Franklin, M., \& Sapir, E. V. (2013). European Parliament election study 2009, voter study. GESIS Data Archive, Cologne. ZA5055 Data file Version 1.1.0. doi: 10.4232/1.11760

Whitten, G. D., \& Palmer, H. D. (1999). Cross-national analyses of economic voting. Electoral Studies, 18, 49-67.

Wlezien, C., Franklin, M., \& Twiggs, D. (1997). Economic perceptions and the vote choice: disentangling the endogeneity. Political Behaviour, 19(1), 7-17.

Woon, J. (2012). Democratic accountability and retrospective voting: A laboratory experiment. American Journal of Political Science, 56(4), 913-930.

\section{About the Authors}

\section{Martin Okolikj}

Martin Okolikj is a PhD Candidate in Political Science at the University College Dublin, School of Politics and International Relations (SPIRe) and a PhD Researcher at the UCD Geary Institute for Public Policy, Ireland. His research interest is in the fields of Political Methodology and Comparative Politics with focus on Elections, Voting Behaviour and Quality of Government.

\section{Dr. Stephen Quinlan}

Stephen Quinlan is Senior Researcher and Project Manager of the Comparative Studies of Electoral Systems (CSES) project at the GESIS Leibniz Institute for the Social Sciences in Mannheim, Germany. His research focuses on electoral behaviour and public opinion including voter turnout, elections, referendums, and examining the impact of social media on politics. 


\section{Appendix}

Table A1. Logistic regression results. Source of data: (van Egmond, van der Brug, Hobolt, Franklin, \& Sapir, 2013; Schmitt, Popa, \& Devinger, 2015)

\begin{tabular}{|c|c|c|c|c|}
\hline Governing Party or Coalition & $\begin{array}{c}(1) \\
2009\end{array}$ & $\begin{array}{c}(2) \\
2014\end{array}$ & $\begin{array}{c}(3) \\
2009\end{array}$ & $\begin{array}{c}(4) \\
2014\end{array}$ \\
\hline \multirow[t]{2}{*}{ Economy } & $0.67^{* *}$ & $0.797^{* *}$ & $0.677^{* *}$ & 0.031 \\
\hline & $(0.054)$ & $(0.05)$ & $(0.142)$ & $(0.165)$ \\
\hline \multirow[t]{2}{*}{ PER } & - & - & $-0.052^{* *}$ & $-0.06 * *$ \\
\hline & & & $(0.007)$ & $(0.013)$ \\
\hline \multirow[t]{2}{*}{ Ideology distance } & $-0.253 * *$ & $-0.069 * *$ & $-0.256 * *$ & $-0.071 * *$ \\
\hline & $(0.009)$ & $(0.013)$ & $(0.01)$ & $(0.013)$ \\
\hline \multirow[t]{2}{*}{ Religion } & $-0.084^{* *}$ & $-0.054 * *$ & $-0.086 * *$ & $-0.055^{* *}$ \\
\hline & $(0.011)$ & $(0.017)$ & $(0.011)$ & $(0.017)$ \\
\hline \multirow[t]{2}{*}{ Economy x PER } & - & - & -0.004 & $0.099 * *$ \\
\hline & & & $(0.02)$ & $(0.02)$ \\
\hline \multirow[t]{2}{*}{ Constant } & $-0.146 * *$ & -0.164 & $0.243^{* *}$ & $0.303^{*}$ \\
\hline & $(0.053)$ & $(0.088)$ & $(0.072)$ & $(0.138)$ \\
\hline $\mathrm{N}$ & 19878 & 6850 & 19498 & 6790 \\
\hline Log Likelihood & -10788 & -4571.8 & -10540.2 & -4516.1 \\
\hline AIC & 21584 & 9151.6 & 21092 & 9044.2 \\
\hline
\end{tabular}

Note: Standard error in parenthesis; ${ }^{*} p<0.05 ;{ }^{* *} p<0.01$.

Table A2. Summary statistics.

\begin{tabular}{|c|c|c|c|c|c|}
\hline 2009 & $\mathbf{N}$ & Mean & St. Dev. & Min & Max \\
\hline Gov. Party & 27.069 & 0.249 & 0.432 & 0 & 1 \\
\hline Economy & 23.088 & 0.085 & 0.278 & 0 & 1 \\
\hline PER & 26.264 & 7.188 & 2.717 & 0 & 10 \\
\hline Ideology distance & 23.647 & 2.738 & 2.128 & 0.022 & 8.959 \\
\hline Religion & 26.549 & 4.181 & 1.572 & 1 & 6 \\
\hline 2014 & $\mathbf{N}$ & Mean & St. Dev. & Min & Max \\
\hline Gov. Party & 13.701 & 0.454 & 0.498 & 0 & 1 \\
\hline Economy & 17.828 & 0.436 & 0.496 & 0 & 1 \\
\hline PER & 28.324 & 7.668 & 2.630 & 0 & 10 \\
\hline Ideology distance & 22.699 & 2.82 & 2.017 & 0.013 & 9.02 \\
\hline Religion & 28.475 & 4.383 & 1.445 & 1 & 6 \\
\hline Bailout/Non-Bailout & 28.986 & $0.28 / 0.72$ & 0.449 & 0 & 1 \\
\hline
\end{tabular}


Table A3. Summary statistics of economy variable by country 2009.

\begin{tabular}{|c|c|c|c|c|c|c|}
\hline Country & $\mathbf{N}$ & Mean & Sd & Median & Min & Max \\
\hline Austria & 875 & 0.05 & 0.23 & 0 & 0 & 1 \\
\hline Belgium & 732 & 0.14 & 0.35 & 0 & 0 & 1 \\
\hline Bulgaria & 768 & 0.12 & 0.33 & 0 & 0 & 1 \\
\hline Cyprus & 747 & 0.16 & 0.37 & 0 & 0 & 1 \\
\hline Czech Republic & 785 & 0.11 & 0.32 & 0 & 0 & 1 \\
\hline Denmark & 868 & 0.11 & 0.32 & 0 & 0 & 1 \\
\hline Estonia & 954 & 0.03 & 0.16 & 0 & 0 & 1 \\
\hline Finland & 902 & 0.03 & 0.17 & 0 & 0 & 1 \\
\hline France & 900 & 0.06 & 0.24 & 0 & 0 & 1 \\
\hline Germany & 898 & 0.08 & 0.26 & 0 & 0 & 1 \\
\hline Greece & 775 & 0.1 & 0.29 & 0 & 0 & 1 \\
\hline Hungary & 909 & 0.06 & 0.24 & 0 & 0 & 1 \\
\hline Ireland & 942 & 0.06 & 0.24 & 0 & 0 & 1 \\
\hline Italy & 782 & 0.1 & 0.3 & 0 & 0 & 1 \\
\hline Latvia & 966 & 0.01 & 0.08 & 0 & 0 & 1 \\
\hline Lithuania & 937 & 0.01 & 0.12 & 0 & 0 & 1 \\
\hline Luxembourg & 849 & 0.08 & 0.28 & 0 & 0 & 1 \\
\hline Malta & 808 & 0.07 & 0.26 & 0 & 0 & 1 \\
\hline Poland & 758 & 0.11 & 0.32 & 0 & 0 & 1 \\
\hline Portugal & 816 & 0.09 & 0.29 & 0 & 0 & 1 \\
\hline Romania & 860 & 0.07 & 0.25 & 0 & 0 & 1 \\
\hline Slovakia & 870 & 0.07 & 0.25 & 0 & 0 & 1 \\
\hline Slovenia & 923 & 0.05 & 0.21 & 0 & 0 & 1 \\
\hline Spain & 850 & 0.17 & 0.37 & 0 & 0 & 1 \\
\hline Sweden & 876 & 0.13 & 0.33 & 0 & 0 & 1 \\
\hline The Netherlands & 873 & 0.09 & 0.28 & 0 & 0 & 1 \\
\hline United Kingdom & 865 & 0.18 & 0.38 & 0 & 0 & 1 \\
\hline
\end{tabular}

Table A4. Summary statistics of economy variable by country 2014.

\begin{tabular}{|c|c|c|c|c|c|c|}
\hline Country & $\mathbf{N}$ & Mean & Sd & Median & Min & Max \\
\hline Austria & 693 & 0.4 & 0.49 & 0 & 0 & 1 \\
\hline Belgium & 670 & 0.5 & 0.5 & 1 & 0 & 1 \\
\hline Bulgaria & 620 & 0.14 & 0.34 & 0 & 0 & 1 \\
\hline Cyprus & 366 & 0.39 & 0.49 & 0 & 0 & 1 \\
\hline Czech Republic & 620 & 0.46 & 0.5 & 0 & 0 & 1 \\
\hline Denmark & 805 & 0.94 & 0.24 & 1 & 0 & 1 \\
\hline Estonia & 616 & 0.47 & 0.5 & 0 & 0 & 1 \\
\hline Finland & 727 & 0.13 & 0.33 & 0 & 0 & 1 \\
\hline France & 760 & 0.08 & 0.27 & 0 & 0 & 1 \\
\hline Germany & 868 & 0.74 & 0.44 & 1 & 0 & 1 \\
\hline Greece & 775 & 0.13 & 0.34 & 0 & 0 & 1 \\
\hline Hungary & 593 & 0.52 & 0.5 & 1 & 0 & 1 \\
\hline Ireland & 751 & 0.72 & 0.45 & 1 & 0 & 1 \\
\hline Italy & 833 & 0.04 & 0.19 & 0 & 0 & 1 \\
\hline Latvia & 607 & 0.48 & 0.5 & 0 & 0 & 1 \\
\hline Lithuania & 572 & 0.57 & 0.5 & 1 & 0 & 1 \\
\hline Luxembourg & 316 & 0.33 & 0.47 & 0 & 0 & 1 \\
\hline Malta & 382 & 0.74 & 0.44 & 1 & 0 & 1 \\
\hline Poland & 568 & 0.28 & 0.45 & 0 & 0 & 1 \\
\hline Portugal & 636 & 0.23 & 0.42 & 0 & 0 & 1 \\
\hline Romania & 674 & 0.35 & 0.48 & 0 & 0 & 1 \\
\hline Slovakia & 562 & 0.29 & 0.45 & 0 & 0 & 1 \\
\hline Slovenia & 772 & 0.25 & 0.43 & 0 & 0 & 1 \\
\hline Spain & 669 & 0.34 & 0.47 & 0 & 0 & 1 \\
\hline Sweden & 607 & 0.69 & 0.46 & 1 & 0 & 1 \\
\hline The Netherlands & 784 & 0.8 & 0.4 & 1 & 0 & 1 \\
\hline United Kingdom & 982 & 0.68 & 0.47 & 1 & 0 & 1 \\
\hline
\end{tabular}


Table A5. Multilevel logit models examining the impact of economic voting in 27 democracies "about the same" is negative in the economy variable. Source: van Egmond, van der Brug, Hobolt, Franklin, \& Sapir, 2013; Schmitt, Popa, \& Devinger, 2015.

\begin{tabular}{|c|c|c|c|c|}
\hline $\begin{array}{l}\text { Dependent variable: Vote for } \\
\text { incumbent govt. }\end{array}$ & $\begin{array}{c}(1) \\
2009\end{array}$ & $\begin{array}{c}\text { (II) } \\
2014\end{array}$ & $\begin{array}{l}\text { (III) } \\
2009\end{array}$ & $\begin{array}{l}\text { (IV) } \\
2014\end{array}$ \\
\hline \multicolumn{5}{|l|}{ FIXED EFFECTS } \\
\hline Economy & $\begin{array}{l}0.633^{* * *} \\
(0.098)\end{array}$ & $\begin{array}{l}0.833^{* * *} \\
(0.165)\end{array}$ & $\begin{array}{r}0.7^{* * *} \\
(0.169)\end{array}$ & $\begin{array}{c}0.373^{*} \\
(0.222)\end{array}$ \\
\hline PER & - & - & $\begin{array}{l}-0.039 * * * \\
(0.006)\end{array}$ & $\begin{array}{l}-0.033^{* * *} \\
(0.01)\end{array}$ \\
\hline Ideology distance & $\begin{array}{l}-0.277^{* * *} \\
(0.009)\end{array}$ & $\begin{array}{l}-0.067 * * * \\
(0.011)\end{array}$ & $\begin{array}{l}-0.278^{* * *} \\
(0.01)\end{array}$ & $\begin{array}{l}-0.067 * * * \\
(0.011)\end{array}$ \\
\hline Religion & $\begin{array}{l}-0.116^{* * *} \\
(0.011)\end{array}$ & $\begin{array}{l}-0.062^{* * *} \\
(0.016)\end{array}$ & $\begin{array}{l}-0.119 * * * \\
(0.011)\end{array}$ & $\begin{array}{l}-0.063 * * * \\
(0.016)\end{array}$ \\
\hline Economy x PER & - & - & $\begin{array}{l}-0.011 \\
(0.021)\end{array}$ & $\begin{array}{l}0.06^{* * *} \\
(0.019)\end{array}$ \\
\hline Constant & $\begin{array}{l}0.017 \\
(0.123)\end{array}$ & $\begin{array}{l}0.013 \\
(0.151)\end{array}$ & $\begin{array}{l}0.313^{* *} \\
(0.131)\end{array}$ & $\begin{array}{c}0.271 \\
(0.17)\end{array}$ \\
\hline RANDOM EFFECTS & & & & \\
\hline Intercept Country by Economy & $\begin{array}{r}0.079 \\
(0.28)\end{array}$ & $\begin{array}{c}0.323 \\
(0.568)\end{array}$ & $\begin{array}{c}0.075 \\
(0.274)\end{array}$ & $\begin{array}{c}0.315 \\
(0.562)\end{array}$ \\
\hline Intercept Country & $\begin{array}{c}0.255 \\
(0.505)\end{array}$ & $\begin{array}{l}0.116 \\
(0.34)\end{array}$ & $\begin{array}{c}0.255 \\
(0.505)\end{array}$ & $\begin{array}{c}0.121 \\
(0.348)\end{array}$ \\
\hline N (Micro/Macro) & $23076 / 27$ & $10702 / 27$ & $22607 / 27$ & 10603 \\
\hline Log Likelihood & -12188.2 & -6796.3 & -11897.8 & -6720.7 \\
\hline AIC & 24388.3 & 13604.6 & 23811.6 & 13457.4 \\
\hline $\mathrm{BIC}$ & 24436.6 & 13648.3 & 23875.8 & 13515.5 \\
\hline
\end{tabular}

Note: Standard error in parenthesis; ${ }^{*} p<0.1 ;{ }^{* *} p<0.05 ;{ }^{* * *} p<0.01$.

Table A6. Multilevel logit models examining the impact of economic voting in 27 democracies "about the same" is positive in the economy variable. Source: van Egmond, van der Brug, Hobolt, Franklin, \& Sapir, 2013; Schmitt, Popa, \& Devinger, 2015.

\begin{tabular}{|c|c|c|c|c|}
\hline $\begin{array}{l}\text { Dependent variable: Vote for } \\
\text { incumbent govt. }\end{array}$ & $\begin{array}{c}(1) \\
2009 \\
\end{array}$ & $\begin{array}{c}(\text { II) } \\
2014\end{array}$ & $\begin{array}{c}(\text { III) } \\
2009\end{array}$ & $\begin{array}{c}\text { (IV) } \\
2014\end{array}$ \\
\hline \multicolumn{5}{|l|}{ FIXED EFFECTS } \\
\hline Economy & $\begin{array}{l}0.487^{* * *} \\
(0.09)\end{array}$ & $\begin{array}{l}0.861^{* * *} \\
(0.139)\end{array}$ & $\begin{array}{l}0.539 * * * \\
(0.131)\end{array}$ & $\begin{array}{r}0.62^{* *} \\
(0.197)\end{array}$ \\
\hline PER & - & - & $\begin{array}{l}-0.036 * * * \\
(0.007)\end{array}$ & $\begin{array}{l}-0.04 * * \\
(0.015)\end{array}$ \\
\hline Ideology distance & $\begin{array}{l}-0.27 * * * \\
(0.009)\end{array}$ & $\begin{array}{l}-0.069 * * * \\
(0.011)\end{array}$ & $\begin{array}{l}-0.272^{* * *} \\
(0.01)\end{array}$ & $\begin{array}{l}-0.07 * * * \\
(0.011)\end{array}$ \\
\hline Religion & $\begin{array}{l}-0.116^{* * *} \\
(0.011)\end{array}$ & $\begin{array}{l}-0.066^{* * *} \\
(0.016)\end{array}$ & $\begin{array}{l}-0.119 * * * \\
(0.011)\end{array}$ & $\begin{array}{l}-0.067^{* * *} \\
(0.016)\end{array}$ \\
\hline Economy x PER & - & - & $\begin{array}{l}-0.009 \\
(0.014)\end{array}$ & $\begin{array}{c}0.032^{*} \\
(0.018)\end{array}$ \\
\hline Constant & $\begin{array}{l}-0.072 \\
(0.124)\end{array}$ & $\begin{array}{l}-0.305^{*} \\
(0.161)\end{array}$ & $\begin{array}{c}0.204 \\
(0.134)\end{array}$ & $\begin{array}{c}0.004 \\
(0.197)\end{array}$ \\
\hline RANDOM EFFECTS & & & & \\
\hline Intercept Country by Economy & $\begin{array}{c}0.086 \\
(0.293)\end{array}$ & $\begin{array}{c}0.216 \\
(0.465)\end{array}$ & $\begin{array}{c}0.085 \\
(0.292)\end{array}$ & $\begin{array}{c}0.213 \\
(0.462)\end{array}$ \\
\hline Intercept Country & $\begin{array}{l}0.25 \\
(0.5)\end{array}$ & $\begin{array}{c}0.272 \\
(0.522)\end{array}$ & $\begin{array}{c}0.248 \\
(0.498)\end{array}$ & $\begin{array}{c}0.275 \\
(0.524)\end{array}$ \\
\hline N (Micro/Macro) & $23076 / 27$ & 10702 & 22607 & $10603 / 27$ \\
\hline Log Likelihood & -12147.7 & -6814.5 & -11860.8 & -6740.6 \\
\hline AIC & 24307.4 & 13641.0 & 23737.5 & 13497.2 \\
\hline $\mathrm{BIC}$ & 24355.6 & 13684.6 & 23801.7 & 13555.4 \\
\hline
\end{tabular}

Note: Standard error in parenthesis; ${ }^{*} p<0.1 ;{ }^{* *} p<0.05 ; * * p<0.01$. 
Table A7. Multilevel logit models examining the impact of economic voting in 27 democracies, dependent variable: Vote for the Head of government party. Source: van Egmond, van der Brug, Hobolt, Franklin, \& Sapir, 2013; Schmitt, Popa, \& Devinger, 2015.

\begin{tabular}{|c|c|c|c|c|}
\hline $\begin{array}{l}\text { Dependent variable: Vote for the } \\
\text { Head of government party }\end{array}$ & $\begin{array}{c}(1) \\
2009\end{array}$ & $\begin{array}{c}\text { (II) } \\
2014\end{array}$ & $\begin{array}{l}\text { (III) } \\
2009\end{array}$ & $\begin{array}{l}\text { (IV) } \\
2014\end{array}$ \\
\hline \multicolumn{5}{|l|}{ FIXED EFFECTS } \\
\hline Economy & $\begin{array}{l}0.84^{* *} \\
(0.15)\end{array}$ & $\begin{array}{l}1.085^{* *} \\
(0.173)\end{array}$ & $\begin{array}{r}0.85^{* *} \\
(0.243)\end{array}$ & $\begin{array}{c}0.523^{*} \\
(0.265)\end{array}$ \\
\hline PER & - & - & $\begin{array}{l}-0.039 * * \\
(0.011)\end{array}$ & $\begin{array}{l}-0.045^{*} \\
(0.019)\end{array}$ \\
\hline Ideology - distance & $\begin{array}{l}-0.417^{* *} \\
(0.015)\end{array}$ & $\begin{array}{l}-0.626 * * \\
(0.022)\end{array}$ & $\begin{array}{l}-0.419 * * \\
(0.015)\end{array}$ & $\begin{array}{l}-0.627^{* *} \\
(0.022)\end{array}$ \\
\hline Religion & $\begin{array}{l}-0.108^{* *} \\
(0.017)\end{array}$ & $\begin{array}{c}0.035 \\
(0.024)\end{array}$ & $\begin{array}{l}-0.111^{* *} \\
(0.017)\end{array}$ & $\begin{array}{c}0.034 \\
(0.024)\end{array}$ \\
\hline Economy x PER & - & - & $\begin{array}{l}-0.004 \\
(0.029)\end{array}$ & $\begin{array}{l}0.073^{* *} \\
(0.026)\end{array}$ \\
\hline Constant & $\begin{array}{l}-0.364 \\
(0.438)\end{array}$ & $\begin{array}{l}-0.146 \\
(0.226)\end{array}$ & $\begin{array}{l}-0.066 \\
(0.442)\end{array}$ & $\begin{array}{c}0.196 \\
(0.269)\end{array}$ \\
\hline RANDOM EFFECTS & & & & \\
\hline Intercept Economy by Country & $\begin{array}{c}0.178 \\
(0.421)\end{array}$ & $\begin{array}{c}0.319 \\
(0.565)\end{array}$ & $\begin{array}{c}0.164 \\
(0.406)\end{array}$ & $\begin{array}{c}0.303 \\
(0.551)\end{array}$ \\
\hline Intercept Country & $\begin{array}{c}4.676 \\
(2.162)\end{array}$ & $\begin{array}{l}0.65 \\
(0.807)\end{array}$ & $\begin{array}{c}4.607 \\
(2.146)\end{array}$ & $\begin{array}{c}0.663 \\
(0.814)\end{array}$ \\
\hline N (Micro/Macro) & $12143 / 27$ & $7916 / 27$ & $11967 / 27$ & $7865 / 27$ \\
\hline Log Likelihood & -5266.7 & -3524.7 & -5166.6 & -3495.5 \\
\hline AIC & 10545.3 & 7061.4 & 10349.1 & 7007.0 \\
\hline $\mathrm{BIC}$ & 10589.7 & 7103.2 & 10408.2 & 7062.8 \\
\hline
\end{tabular}

Note: Standard error in parenthesis; ${ }^{*} p<0.05 ;{ }^{* *} p<0.01$.

Table A8. Multilevel logit models examining the impact of economic voting in 27 democracies, Ideology independent variable. Source: van Egmond, van der Brug, Hobolt, Franklin, \& Sapir, 2013; Schmitt, Popa, \& Devinger, 2015.

\begin{tabular}{|c|c|c|c|c|}
\hline $\begin{array}{l}\text { Dependent variable: Vote for } \\
\text { incumb. govt. }\end{array}$ & $\begin{array}{c}(I) \\
2009\end{array}$ & $\begin{array}{c}(I I) \\
2014\end{array}$ & $\begin{array}{c}(I I I) \\
2009\end{array}$ & $\begin{array}{c}\text { (IV) } \\
2014 \\
\end{array}$ \\
\hline \multicolumn{5}{|l|}{ FIXED EFFECTS } \\
\hline Economy & $\begin{array}{l}0.763 * * \\
(0.134)\end{array}$ & $\begin{array}{l}1.214^{* *} \\
(0.2)\end{array}$ & $\begin{array}{l}0.819 * * \\
(0.19)\end{array}$ & $\begin{array}{c}0.615^{*} \\
(0.256)\end{array}$ \\
\hline PER & - & - & $\begin{array}{l}-0.04 * * \\
(0.007)\end{array}$ & $\begin{array}{l}-0.041 * * \\
(0.014)\end{array}$ \\
\hline Ideology & $\begin{array}{l}0.073 * * \\
(0.007)\end{array}$ & $\begin{array}{l}-0.046 * * \\
(0.009)\end{array}$ & $\begin{array}{l}0.074^{* *} \\
(0.007)\end{array}$ & $\begin{array}{l}-0.046^{* *} \\
(0.009)\end{array}$ \\
\hline Religion & $\begin{array}{l}-0.102^{* *} \\
(0.012)\end{array}$ & $\begin{array}{l}-0.045^{*} \\
(0.019)\end{array}$ & $\begin{array}{l}-0.106^{* *} \\
(0.012)\end{array}$ & $\begin{array}{l}-0.041^{*} \\
(0.02)\end{array}$ \\
\hline Economy x PER & - & - & $\begin{array}{l}-0.01 \\
(0.02)\end{array}$ & $\begin{array}{l}0.078^{* *} \\
(0.021)\end{array}$ \\
\hline Constant & $\begin{array}{l}-1.208^{* *} \\
(0.133)\end{array}$ & $\begin{array}{l}-0.387^{*} \\
(0.185)\end{array}$ & $\begin{array}{l}-0.903^{* *} \\
(0.142)\end{array}$ & $\begin{array}{l}-0.094 \\
(0.215)\end{array}$ \\
\hline RANDOM EFFECTS & & & & \\
\hline Intercept Economy by Country & $\begin{array}{c}0.192 \\
(0.438)\end{array}$ & $\begin{array}{c}0.484 \\
(0.695)\end{array}$ & $\begin{array}{c}0.184 \\
(0.429)\end{array}$ & $\begin{array}{l}0.477 \\
(0.69)\end{array}$ \\
\hline Intercept Country & $\begin{array}{c}0.159 \\
(0.399)\end{array}$ & $\begin{array}{c}0.113 \\
(0.337)\end{array}$ & $\begin{array}{c}0.167 \\
(0.408)\end{array}$ & $\begin{array}{c}0.112 \\
(0.335)\end{array}$ \\
\hline N (Micro/Macro) & $19924 / 27$ & $7916 / 27$ & $19583 / 27$ & $7865 / 27$ \\
\hline Log Likelihood & -10624.7 & -4881.2 & -10407.6 & -4844.1 \\
\hline AIC & 21261.5 & 9774.4 & 20831.2 & 9704.2 \\
\hline $\mathrm{BIC}$ & 21308.9 & 9816.2 & 20894.3 & 9760.0 \\
\hline
\end{tabular}

Note: Standard error in parenthesis; ${ }^{*} p<0.05 ; * * p<0.01$. 
Table A9. Multilevel logit models examining the impact of economic voting in 27 democracies for 2009 and 2014 EP elections. Source: van Egmond, van der Brug, Hobolt, Franklin, \& Sapir, 2013; Schmitt, Popa, \& Devinger, 2015.

Dependent variable: Vote for the incumbent gov.

\section{FIXED EFFECTS}

Economy

PER

2014

Ideology distance

Religion

Economy $\times$ PER

Economy x 2014

PER $\times 2014$

Economy x PER x 2014

Constant

\section{RANDOM EFFECTS}

Intercept Economy by Country

Intercept Country

N (Micro/Macro)

Log Likelihood

AIC

BIC

Note: Standard error in parenthesis; ${ }^{*} p<0.05 ;{ }^{* *} p<0.01$.
(I)

Pooled model
$0.845^{* *}$
(0.196)
$-0.039 * *$
(0.007)
$0.587 * *$
(0.127)
$-0.197^{* *}$
(0.008)
$-0.102^{* *}$
(0.011)
$-0.007$
(0.02)
$-0.297$
(0.229)
$-0.001$
(0.016)
$0.076 *$
(0.03)
$-0.031$
(0.132)
0.226
(0.475)
0.108
(0.328)
26288/27
$-14389.0$
28801.9

28900.1

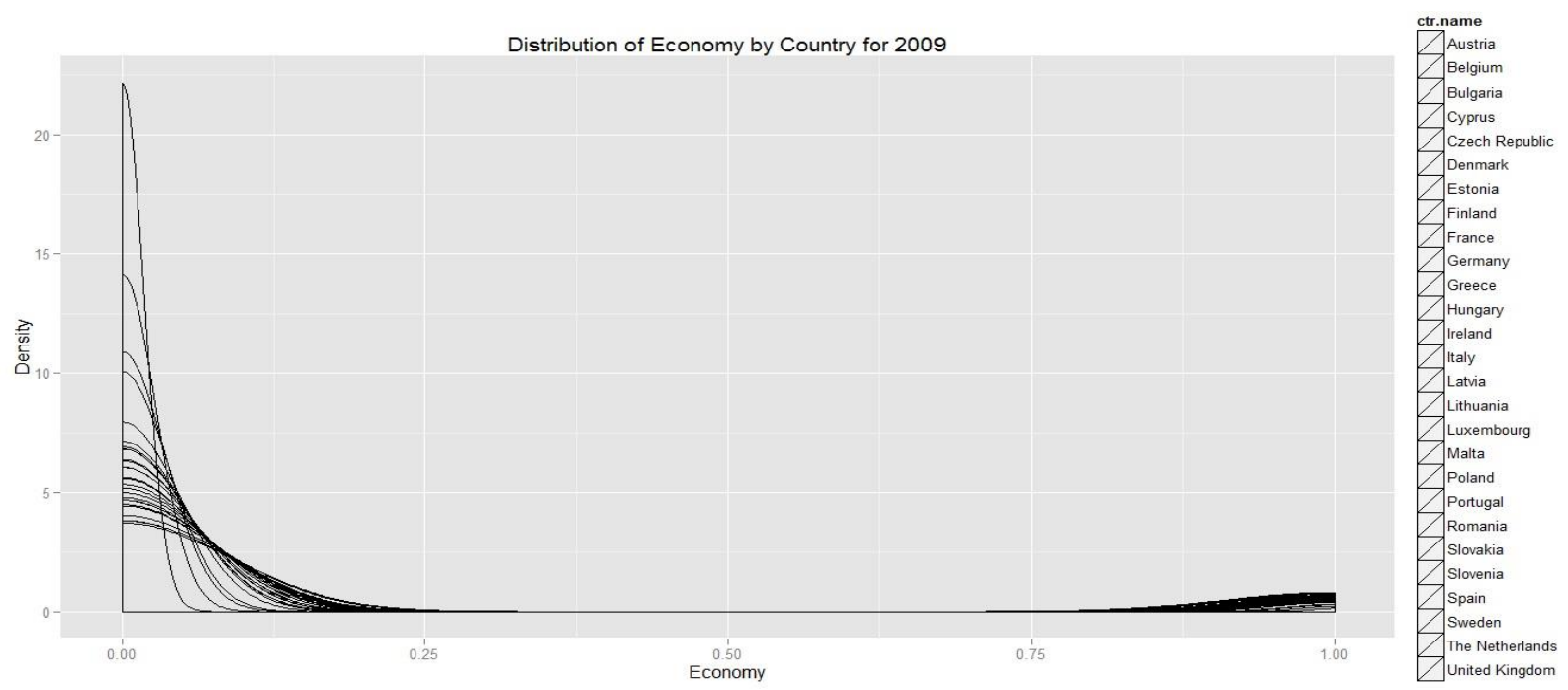

Figure A1. Distribution of economy by country for 2009. 


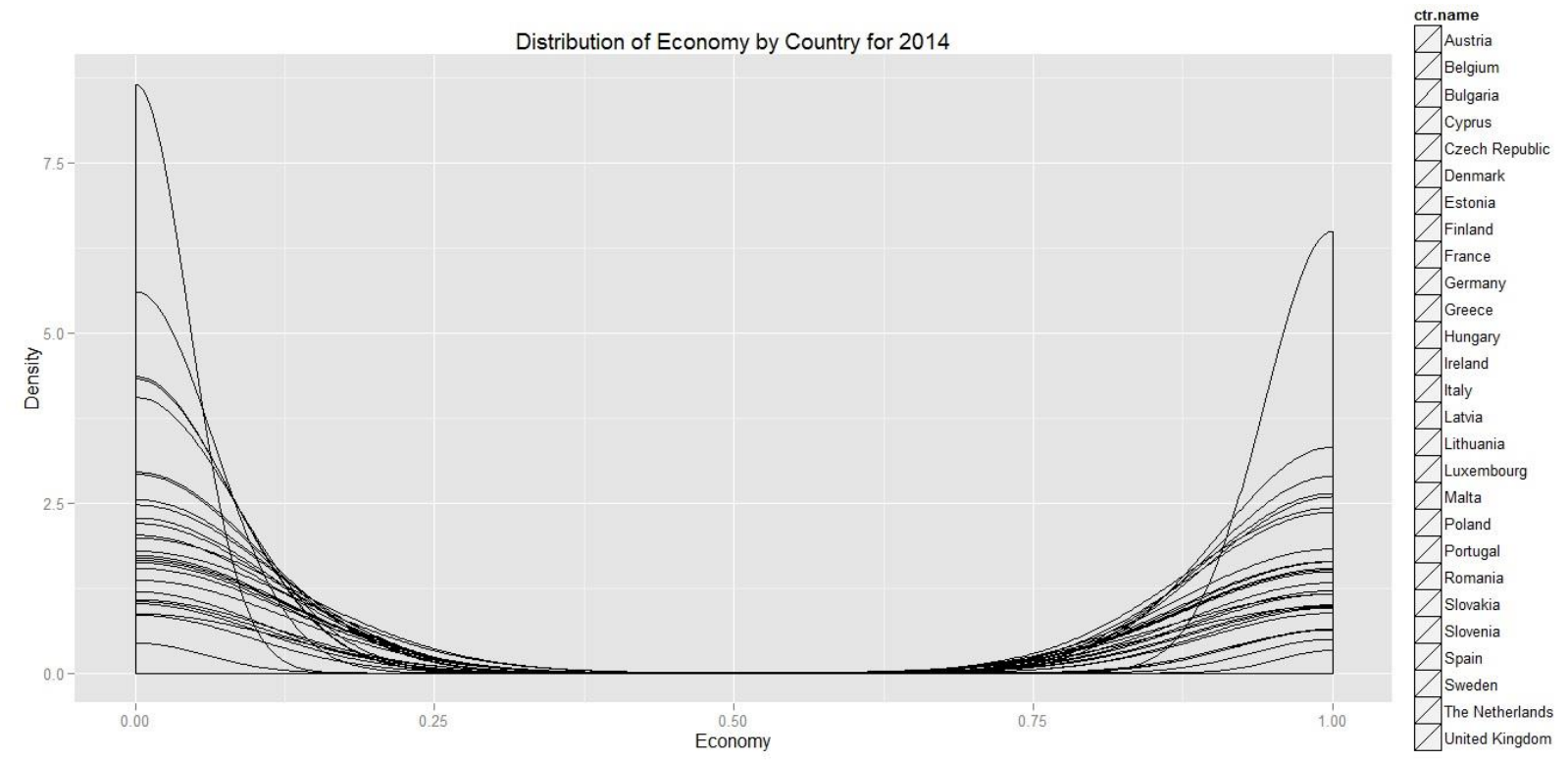

Figure A2. Distribution of economy by country for 2014.

\section{Interaction plot 2014}

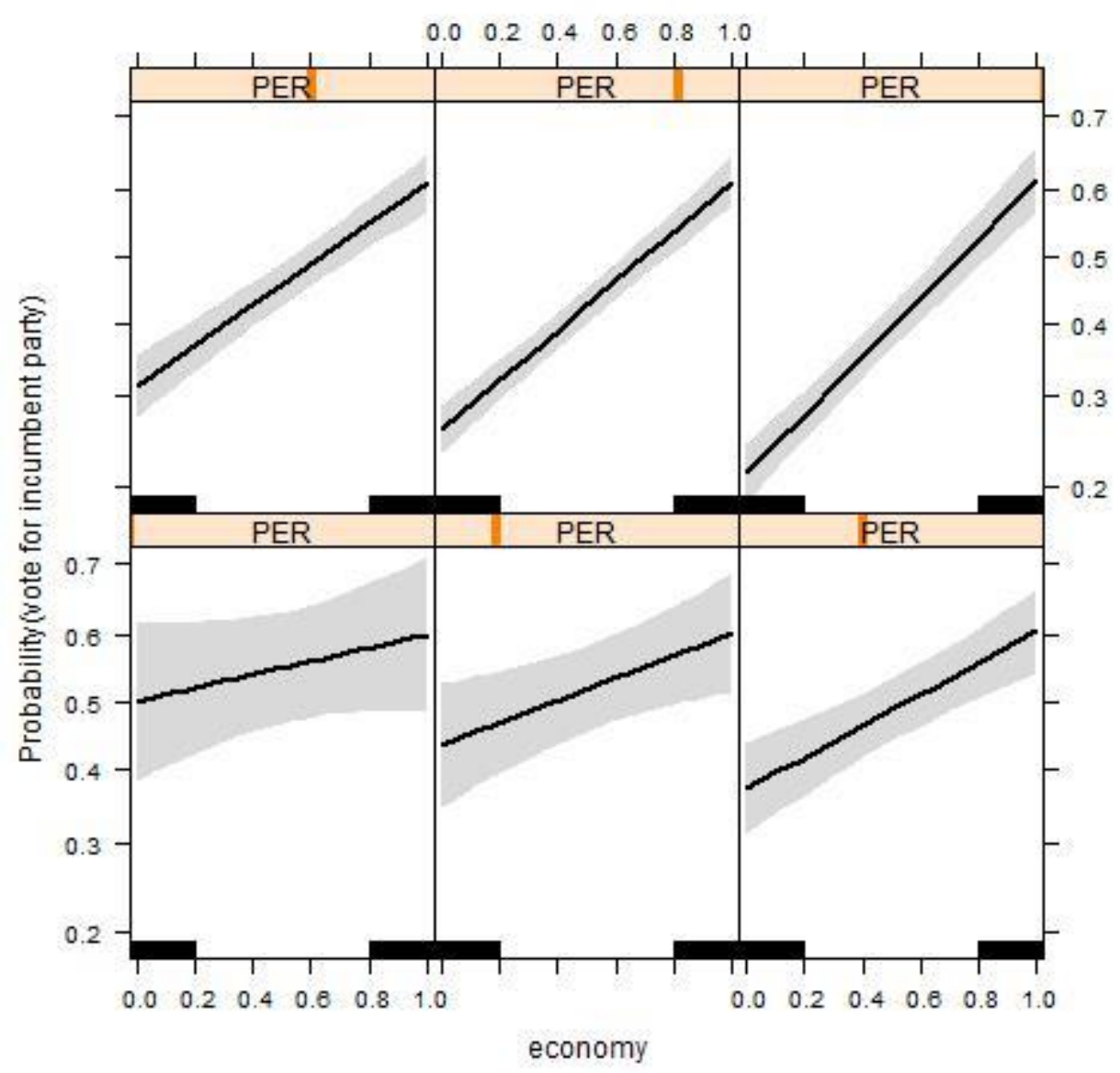

Figure A3. Interaction effect plots between economy and PER among Bailout countries for 2014 EP election. Note: The upper right plot indicates that PER is at the highest level. The lower left plot indicates that PER is at the lowest level. 


\section{Interaction plot 2014}

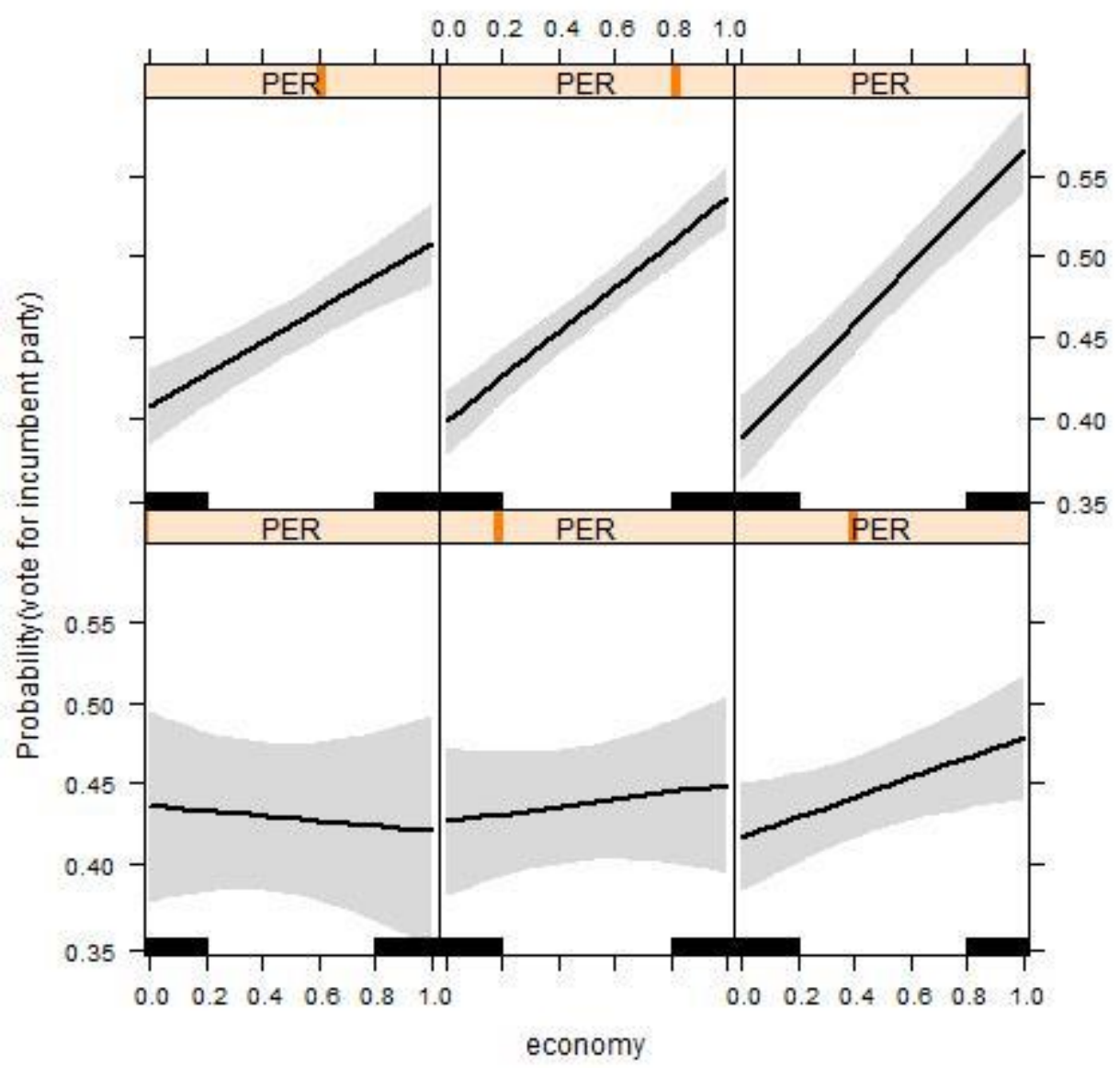

Figure A4. Interaction effect plots between economy and PER among non-bailout countries for 2014 EP election. Note: The upper right plot indicates that PER is at the highest level. The lower left plot indicates that PER is at the lowest level. 